\title{
NOTES ON AMASIS AND IONIC BLACK-FIGURED POTTERY.
}

\author{
[Plates V., VI.]
}

Among the artists who have signed Attic black-figured vases perhaps the most singular and interesting personality is the potter and painter Amasis. He is interesting both as one of the masters of that delicate decorative work, which gives b.f. vases their artistic value, and through the curious contradictions which can be traced in his style. Only seven vases bearing his signature are known up till now, ${ }^{1}$ yet each shows characteristic peculiarities of shape, decoration, or style, which one would seek for in vain among the mass of contemporary Attic pottery.

No artist has surpassed Amasis in easy mastery and accuracy of drawing, or in the painstaking, delicate treatment of detail; yet his figures are often rigid and affected, his choice of subjects monotonous and limited. The technique and style of his vases, the alphabet and dialect of their inscriptions prove that he worked in Athens; yet both his numerous peculiarities of style and his name seem to denote a foreign origin.

It is but natural that so peculiar and interesting an artist should have excited curiosity to trace his origin and influence, and the wish to enrich the scanty stock of his work which we possess, by unsigned vases that may be attributed to him. Studniczka (Ephem. Archacol. 1886, 117, Pl. 8, 3) has published a fragment of an amphora found on the Acropolis of Athens, which he considers, with some probability, to be a work of Amasis, and has added some interesting remarks on the artist's origin. Fossey (Rev. Archéol. 1891, xviii. 367) has drawn attention to two vases in which he recognises the style of Amasis; we shall revert to these below. But by far the most important addition to our material is the beautifyl amphora recently acquired by the Museum of Berlin, which Furtwängler (Arch. Anz. 1893, 83) has first recognized as one of the best works by Amasis' hand. This amphora has since been accurately published by Adamek (Unsignirte Vasen d. Amasis, 1895), who has added to it a series of other vases which he attributes to the same master. This latter question will be examined later. But first we must add to the list of Amasis' work a new un'signed amphora, which forms

1 Two amphorae and four jugs published Wiener Vorlegebl. 1889, 3, 4. An unpublished amphora quoted by Hauser Archaeol. Jahrb.
1896, 178 note 1 . That the amphora in the Brit. Mus. bearing the name Amasis is not by our artist, will be shown below. 
the exact counterpart of the one in Berlin, and is at the same time one of his finest and most interesting productions.

The amphora figured on Pl. V. and fig. $1,{ }^{1}$ now in the Museum of Wiurzburg (331 Urlichs) originally belonged to the Feoli collection; we may thus in all probability assume it to have been found at

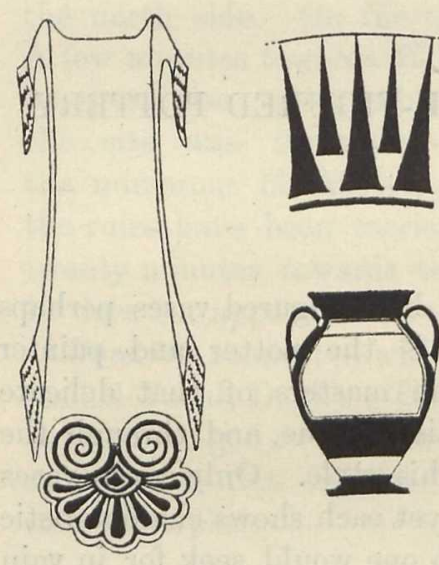

FIG. 1. Vulci. Its resemblance to the amphora in Berlin is too striking and complete to admit any doubt of its authorship. Both vases have the same rather heavy and unwieldy shape, the neck not being distinct from the body, the same proportions and profiles of the mouth, foot and handles; instead of the tubular handles more usually employed for b.f. amphorae of this shape, these are grooved on the outside (for their shape see the initial letter of Adamek's treatise), and their ends are ornamented with a pattern of short lines, zig-zag ${ }^{2}$ on our amphora, straight lines on the Berlin one (if Adamek's drawing is correct). Even more strikingly alike is the decoration of both vases: a large panel is reserved on each side, divided into the main picture and a frieze of tiny figures, about one-fifth of the whole panel in height, above it. ${ }^{3}$ I know no other Attic example of this peculiar system of decoration. Two Chalcidian amphorae of the same shape (Petersburg 54=Loeschcke Bonner Stud. 256, and Louvre E 802) show similar panels divided into two pictures; but here the upper one is about half as high as the lower, and by the choice of subjects for the former (mostly animals) the disproportion of size is as much as possible obliterated. The same principle is observed on two Ionic amphorae, akin in style to the well-known Phineus kylix, which were formerly in Comm. Castellani's collection in Rome, and of which Prof. Loeschcke has kindly communicated tracings to me (cf. Bulle, Silene p. 8, No. 14); further on a Chalcidian amphora in the Museo Faina at Orvieto, ${ }^{4}$ different in shape. But in all these cases the upper pictures are about one half as high as the lower, and thus unlike the friezes

1 For Herr Gaab's drawings (which have been so far modified as is necessary for the purpose of general publication), and for permission to publish them, I am indebted to the liberal kindness of Prof. Sittl. I also wish to express my gratitude to Dr. Boehlau, who had intended to publish this vase, and very kindly gave up his plan in my favour.

2 This ornament, not frequent in Attica, is constantly used on the finest Chalcidian vases and on Corinthian 'anfore a colonnette.'

3 On the Berlin vase the panels are framed on each side by a maeander, and the upper frieze divided from the main picture by a plait pattern, an unusual one in Attica; the Wiirzburg amphora has no ornamental patterns, the pictures being framed by plain double lines.

4 This vase, unhappily in a very fragmentary condition, is of peculiar interest, as it combines a neek distinct from the body, with reserved panels for the pictures: (a) a youthful horseman opposite a man draped in a chlamys. (b) two sphinxes seated heraldically opposite each other. In each of the upper pictiores, remains of two animals. 
of tiny figures on our amphora. Still it is important to note that the only analogies to this peculiar scheme of decoration are found outside of Attica, on Ionic vases.

Another detail of decoration which both our amphorae have in common, while it is distinctly foreign to Attic art, is the donble row of rays (Fig. 1) tapering upward from the base. In Appendix II. to this article I have tried to trace the origin and development of this pattern, which, we shall see, is characteristic of Amasis, and again connects his work with Ionic art.

The analogy of shape and ornamentation between the two vases is entirely corroborated by their style. In the small frieze of the Wirzburg amphora, on the obverse, Dionysos is seated on a folding chair, a drinking horn in his hand, surrounded by a wild dance of alternate Sileni and Maenads. On the reverse there are more dancing Maenads and Sileni, one of whom is playing a double flute. An exactly similar frieze is painted on the obverse of the Berlin amphora, some of the figures being almost identically alike in both cases. The same identity of style is evident in the main pictures. The reverse offers a subject frequent on b.f. vases : Dionysos, walking to the left, clad in a long himation, a wreath of vine-leaves in his long flowing hair, a bunch of vine branches in his left hand. In his right he holds a large kantharos, into which a Silenus, his face drawn in front view, is pouring wine from a skin. Behind him a second Silenus plays the double flute, a wreath hanging on his arm, while to the right of Dionysos two others trip along, drinking-horns in their hands, and their arms twined about each other's necks in the scheme which is peculiar to Amasis, and is found both on the Berlin amphora and on the famous signed one in the Cabinet des Médailles. The scene on the obverse is more unusual and interesting. ${ }^{1}$ Under a trellis of vines a large wicker basket has been placed in a flat trough resting on trestles; a Silenus is standing in the basket, stamping the grapes, which another throws into it out of a flat, probably wooden tray, the end of which is seen above his neck; while a third Silenus, to the right, is gathering grapes off the vine. A large jug stands under the trough, from which the must flows through a spout into a large pithos sunk deep into the earth. Next to this pithos, a kantharos is standing on the ground, and behind it a Silenus plays the flute, while another is pouring water from a hydria into a large pithos standing almost wholly above ground. The whole is drawn with great skill and care, and the scene is full of life and humour. The Sileni are ithyphallic on both sides, most of them with an entirely stippled, hairy body, long beards and mane-like hair (especially bestial in the one with the hydria); their faces have the expression of brutal, yet harmless and merry bestiality which is characteristic of Amasis' Sileni.

Altogether, we will not hesitate to add the Würzburg amphora to the list of the best and most careful works by our artist's hand; it is, in fact, his

1 Examples of Sileni engaged in grape-picking are rather rare; a specially characteristic one, very similar to the Wizrzburg amphora in subject, though not in style, Gerhard A.V. 15 ; cf. an amphora and a cylix by Niknsthenes, Wien. Vorlegeb7. 1890-1, 3,5. 
most vigorous and lifelike production. It may be added that the edge of Dionysos' himation is fringed, a detail which Adamek (l.c. p. $12 \mathrm{ff}$.) regards as equivalent to Amasis' signature. It does appear on all his work, but Adamek himself has given a long list of other vases with fringed dresses, which proves how exaggerated his conclusion is.

By reproducing the Berlin amphora, Adamek has rendered an undoubted service, and it is certainly useful too to have the drawings of the other vases which he attributes to Amasis. Furtwängler had already collected the amphorae of the Berlin Museum in his catalogue (1688-1692, and the jug 1731), and called attention to their excellence of technique and accuracy of style. Adamek's work has been mainly restricted to the publication of these vases (Fig. 3-16 of his treatise), and to the tracing of fringes on each of them; he has likewise found fringes on the two vases published by Fossey (Rev. Archéol. 1891, 367 : Brit. Mus. B 52 and Louvre F 26), and already connected by him with Amasis; and the same detail seems to Adamek a sufficient reason for attributing to the same master five vases as different in style as Berlin $\mathbf{1 6 8 6}$ (Etr. camp. Vas. 2/3), Brit. Mus. B 197 (Walters, Pl. 5-6.), Mus. Greg. II. 3 (Diimmler Roem. Mitth. 1887, 190), Munich 81 (Gerhard A.V.121-2) and 75.

I have already said that Adamek's own list (p. 14-15) is the best proof that fringed dresses are not, as he terms it, a kind of signature of Amasis, but a detail which, while it constantly appears on the vases by his hand, is not unfrequent in Attic b.f. and r.f. painting generally. Of the five vases last quoted, the first four are as like or unlike Amasis' work as any carefully executed Attic vase of the same period. ${ }^{1}$ As for the other vases, they do really form a series which shows a marked resemblance to the style of Amasis, and probably were made in his workshop, though not, I think, by his own hand. The following examples are known to me (Nos. 8-12, 15 are new) :-

\section{I.-Amphorae.}

1-5. Berlin 1688-1692. Adamek Fig. 2-13. 16.

6. Munich 75. Adamek p. 43-4. Furtwängler, Münchener Führer, p. 28, who claims the vase for Amasis ; it certainly is most strikingly similar to his work.

7. Louvre F 26. Fossey (Rev. Arch. 1891, 367), has published one panel, a naked youth with a hare in his hand, between three men. On the reverse, a man clad in a short chiton and pointed cap, holding a lance and a shield with a lion's head in relief, stands between two men and a youth with four wings, of which two are recurved, exactly like the Gorgon's on one of Amasis' jugs (Wien. Vorl. 1889, 4).

8. Louvre F 25. A small and unusually delicate and beautiful vase. (a) Warrior in full armour, but without a shield (his chiton fringed), holding a dog by a chain, and a wreath, is talking to Poseidon, clad in a long embroidered

1 Berlin 1686 resembles Amasis in style, but is probably somewhat older. 
NOTES ON AMASIS AND IONIC BLACK-FIGURED POTTERY. 139

chiton and chlamys, and holding a trident. On the other side a woman, in the sleeved chiton of Amasis' Maenads, holding lance and wreath. (b) Dionysos with kantharos and vine branch, between Hermes (wearing petasos and winged shoes, holding kerykeion) and a youth with two lances.

9. Louvre F 36. (a) Herakles attacking a warrior (shield, with the forepart of a lion), between a woman holding lance, and another warrior (shield, with snake in relief). (b) Dionysos with kantharos between two dancing couples.

10. Brit. Mus. B 151. (a) Youthful rider to $\mathrm{r}$. holding a second horse, a boy running underneath him; on either side a naked youth and a longrobed man. (b) Two warriors with blank round shields to l., between them a $\mathrm{dog}$; on either side a long-robed man with a lance. Double rays round the base, the only example in this series.

11. Orvieto, Museo Faina 40. (a) Man standing to $r$. in linen chiton and fringed himation; Hermes opposite, touching his chin with his right hand, then Athena, Herakles (bow, sword, club, without lion's skin, but a lion by his side), Dionysos with drinking horn, all of them to 1 . (cf. Berlin 1691). (b) 'Persian Artemis,' with four wings, holding lion by hind paws and doe by neck; on either side two youths, in chlamys and himation respectively.

12. Chiusi, Museo Municipale. (a) Dionysos and Ariadne (her flesh drawn in outline) opposite each other, between three Sileni. (b) Quadriga with warrior, two warriors behind it.

$$
\text { II.-Jugs. }
$$

13. Berlin, 1731. Adamek Fig. 14-15.

14. Brit. Mus. B 52. Fossey l.c. Important as having been found at Rhodes.

15. Louvre F 28. Man fastening his second greave on his leg, his helmet between his legs, a woman opposite holding shield and lance. On either side two naked youths, and on one side a long-robed man, all holding lances.

This list could no doubt be considerably enlarged, but for our purpose it is amply sufficient. There is hardly a class of works of art in which stylistic criticism is so dangerous and misleading as the Attic b.f. vases, with their conventional treatment of types and myths which for the most part have been created elsewhere and taken over ready-made by the Athenian potters. One cannot be too careful in attributing unsigned work to any known artist, and when that artist has marked and unique peculiarities of style and treatment, it is a mistake to blur our conception of his art by attributing to him vases which merely resemble his work, or have been made under his direct influence. Now no other painter of his time has a more characteristic style than Amasis. Not only are his methods of decorating the amphora utterly unlike the ordinary Attic types, but numerous details, like the drawing of women's flesh 
in black outline, ${ }^{1}$ the Bacchic couples with arms clasped round each other's necks, the peculiar zig-zag folds of the chiton (Wien. Vorl. 1889, 4, 4; Adamek Pl. 1), would be sought for in vain among the vast number of Attic b.f. vases; and the double rays round the base are at least as conclusive as Adamek's fringes, since, besides a crater by Nikosthenes, they occur, to my knowledge, on only two Attic vases, both under Amasis' direct influence : the amphora Brit. Mus. B 151, just quoted, and the psykter B 148 which we shall examine below. For these reasons I consider the two unsigned amphorae in Berlin and Wiirzburg to be undoubtedly by Amasis himself, while I am unable to admit this for the others.

It may be permitted, as we are treating this subject, to recur briefly to the amphora Brit. Mus. B 209 (Wien. Vorl. 1889, 3, 2), on which the name of Amasis has been explained as a signature of the artist. Adamek has reverted to this explanation, which Loescheke $(A . Z .1881,31)$ and Cecil Smith (text of the Wien. Vorl.) would seem to have rendered untenable, by showing the impossibility of explaining the inscription as a signature, and pointing out that the vase in its style resembles Exekias, not Amasis. I would add that 'the artificial folds of the chiton' of Achilles and Memnon, quoted by Adamek in defence of his assertion, are just not like the typical zig-zag folds of Amasis; and that among all the numerous warriors on Amasis' vases not one has a metal armour such as Achilles and one of the negroes wear, ${ }^{2}$ not one a leather armour entirely resembling Memnon's, nor the peculiar tassels inside the shields, nor the mode of dressing the hair with its three separate curls which we see in the case of both heroes. This amphora must be definitively struck off the list of Amasis' works.

We have thus altogether five amphorae and four jugs which we can safely attribute to Amasis' own hand. The jugs are all of the same shape and scheme of decoration, a type which the Athenian potters received from Corinth (a Corintho-Attic example, Vienna 123 Pl. 1 Masn.); while it is remarkable that the five amphorae present four distinct types, each different from the ordinary Attic ones. The Paris amphora, with its narrow frieze of warriors on the shoulder, shows a scheme of decoration corresponding to the best Chalcidian amphorae, while only solitary examples, most of them clearly bearing the mark of foreign influence, occur among Attic ware. ${ }^{3}$ Nor is the decoration of the Amasis amphora in Mr. Bourguignon's collection (Wien. Vorl. 1889, 3) at all an habitual one, two purely decorative figures

\footnotetext{
1 The same technique is employed by Cholchos (Wien. Vorl. 1889, 1), but it is only one isolated example; Amasis gives women's flesh in white also, mostly for small figures, as on the upper friezes of the two unsigned amphorae.

${ }^{2}$ On the contrary, this armour finds its exact counterpart on the amphora by Exekias (Wien. Vorl. 1888, 6, 2), which gives the same myth in an almost identical manner.

3 Two very fine examples in the Museo
}

Municipale of Orvieto, especially one resembling Amasis in the palmettes under the handles and the decoration of each side by only three large figures (a) Apollo between Aphrodite and Artemis, (b) Zeus with the new-born Athena on his knee, between two Eileithyiae). The other examples mostly have no special resemblance to Amasis' style ; e.g. Brit. Mus. B 212, 213 (Micali Storia 85) Louvre F 199, 216. Berlin 1713, 1716, 1717. Strassburg Univ. Mus. 
of Dionysos under the handles being substituted for the usual Attic palmette and lotos ornament. The second amphora belonging to Mr. Bourguignon seems, according to Hauser's description, to resemble the ordinary Attic type with red body. While the two unsigned vases in Wuirzburg and Berlin find their only parallels in Chalcis and Ionia (see above).

I think that another rare type of vase may be traced back to Amasis, even though we have no example of it actually painted by him. On Pl. VI. is figured one of the most accurate and delicate b.f. vases of the British Museum, the psykter B $148^{1}$; it is one of a small series of amphorae with a double bottom and a spout on one side, the wine being poured in through the neck, the cooling water through the spout. ${ }^{2}$ This is the typical b.f. type of the psykter, and its ingenious arrangement corresponds exactly to the predilection for such vases with special contrivances, evident during the archaic period. ${ }^{3}$ The later type of the psykter, which is merely a vase containing wine and floating on the water in a large crater, I take to be an invention of r.f. ceramic art; at least I know no b.f. example anterior to the severe r.f. style. $^{4}$ On the other hand; our type of the psykter is distinctly archaic, and represented by a small series of Chalcidian vases, which we may hope soon to see published by Loeschcke. The finest example of all is in Copenhagen (Daremberg-Saglio l.c.); another belonging to the Berlin Museum is figured in the Archaeolog. Anzeiger 1889, 91; two more are in the Museo Municipale at Corneto and in Comm. Castellani's collection in Rome, the latter being specially interesting through a stippled Silenus closely resembling those on our vase. Fragments of a fifth psykter of the same kind are in Mr. Bourguignon's collection at Naples.

The Chalcidian examples all have the neck distinct from the body, while ours is of the ordinary shape of Attic b.f. amphorae with reserved panels, the spout alone distinguishing it. ${ }^{5}$ This spout is decorated with rays and a zigzag pattern which we find both on Chalcidian vases and on the handles of the Amasis amphora at Wuirzburg. The lotos and palmette chain above the pictures, frequent in b.f. art, finds its counterpart on the jugs by Amasis, and the double rays at the base of the psykter are, as we have seen, characteristic of all his work. Further resemblances are noticeable in the style of the panels. Their subjects need no explanation: on one side ${ }^{6}$ Theseus, wearing

1 From a drawing by Mr. F. Anderson, which Mr. G. F. Hill kindly procured for me; I am also indebted to Mr. Murray for his kind permission to publish this vase.

${ }^{2}$ See Daremberg-Saglio i. 2, 821, Fig. 1026 ; the water was emptied out of the vase through a hole in the bottom.

3 Cf. M. Pottier's valuable article on the beautiful Corinthian vase published B.C.H. xix. Pl. 19-20. I know several other examples of such vases with secret contrivances, all of them belonging to the seventh and sixth centuries.

4 The oldest example known to me is figured on the oinochoe by Xenokles and Kleisophos (Wien. Vorl. 1889, 1). Existing psykters of this shape, e.g. Louvre F. 319, 320, 488. L 131. Brit. Mus. B 299. One in Dr. Hauser's collection, now in Leipzig, one in the Museo Municipale at Corneto.

5 Another example of this type, Naples, Coll. Santang. 38 Heydem., also Attic, and of similar, though less characteristic, style. Simple rays, ivy wreath on spout and grooved handles.

6 The vase was intended to be placed with the spout-side backward, as is here indicated by the chief subject being reserved for the other panel. 
only a curious loin-cloth with a rosette embroidered upon it, ${ }^{1}$ is driving his sword into the neck of the stippled Minotaur, while with his left hand he seizes the monster's left wrist. 'Theseus' chlamys is lying between his legs on a stone or mound of earth, the sheath of his sword hangs behind his back. On either side two Athenian youths are regarding the scene with interest, two of them draped in a long embroidered himation, the third naked, the fourth with a short chlamys thrown over his shoulders. All have most elaborately dressed hair. On the other panel, Dionysos, wreathed with ivy and dressed in an embroidered chiton and red chlamys, stands stiffly, a drinking horn in his left hand; before him is a stippled Silenus gesticulating. On the other side of the spout, two similar Sileni and a Maenad in a red Ionic chiton with a nebris tied over it, are dancing along, while under the spout a smaller Silen, not stippled, is trying to catch a hare.

The general style of the youths, with their elaborate head-dress, elongated limbs and stiff postures, and especially of the stippled Sileni with horses' ears and bestial faces, closely resembles Amasis' work, and the hare in the Bacchic scene is also suggestive of his influence (see the amphorae in Berlin and Paris). Yet I do not think that the psykter is by his hand. The type of Dionysos is different: Amasis always gives him the kantharos, not the drinking horn (except in the upper frieze of the Wuirzburg amphora), and a different style of clothing. The same applies to the Maenad, whose dress is quite different from the peculiarly characteristic chiton with short slit sleeves which Amasis uses (see the amphorae in Paris, Würzburg, Berlin), while he avoids the nebris; besides, the Maenad on the psykter has her flesh painted white, not drawn in black outline, as Amasis draws it on his best work. Even the Sileni do not quite render Amasis' type: they are not ithyphallic and their faces are stippled, while Amasis restricts this indication of hair to the body:

If, thus, a conscientious examination does not allow us to attribute the psykter to Amasis himself, its many analogies of decoration and style make it evident that the vase was made under the direct influence of that master. And so we may attribute to him the importation with modifications of the Chalcidian type of the psykter into Attica; a supposition which is confirmed by the fact that the unique type of the two unsigned amphorae by Amasis in Berlin and Würzburg corresponds to a Chalcidian one (see above), and that here also Amasis has modified the type, by reducing the upper picture of the amphora to a narrow, almost decorative frieze. It is impossible to say whether he drew his models from Chalcis itself or copied a common Ionic prototype; in the case of the amphora, the latter is rendered probable by

1 The loin-cloth is of exactly the same cut as the garment showing under the cuirass of Chalcidian warriors, and the rosette too is quite Chalcidian, and unusual in Attica at this period. On a b.f. hydria of ordinary Attic style in the Museo Gregoriano (ii. 8) we find
Theseus, who is killing the stippled Minotaur, clad in exactly the same loin-cloth decorated with a rosette. A similar garment without the rosette is worn by a youth on the amphora, Berlin 1686 (see above p. 138). 
NOTES ON AMASIS AND IONIC BLACK-FIGURED POTTERY. 143

the two Ionic examples quoted above. Of the psykter we have as yet found no traces in Ionia.

Thus we see in Amasis an artist, working doubtless in Athens, as his inscriptions prove, a consummate master of Attic b.f. style, employing current Attic shapes and types, yet trying constantly, both in the shapes of his vases, in the scheme of their decoration, and in details of technique and style, to introduce new elements, derived from foreign sources, into the monotonous rigidity of Attic b.f. art. The drawing of women's flesh in black outline, the stippled Sileni, the couples with their arms clasped round each other's necks, the naked Maenads with their great ear-rings, the invariable leather cuirasses with shoulder-flaps, worn by the warriors, the fringed garments and their rich embroidery and curious folds, the complicated head-dress of the men, are all so many signs of Ionic influence; and these signs could be multiplied by a detailed examination of Amasis' work. Here, I merely quote the type of the Gorgon and the bearded Perseus, the panther's skin of the Maenad on the Parisian amphora, the episema of the shields, like the Asiatic stag (dama vulgaris, an animal known only to eastern Ionic art) or the panther's mask, which I shall show to be an Ionic type in my publication of the gold ornaments from Camirus; further, the Scythian archer and the man blowing the bugle on the shoulder frieze of the Parisian amphora, and-assuming the fragment published by Studniczka to be by Amasis-Athena's helmet with its phalos (Loeschcke, Festschr. d. Bonner Jahrb. 1891, 10) and its band of lotos flowers and pomegranates. Everywhere we see the influence exercised over Amasis by foreign models, whereas his own influence in Attica seems to have been a small one. We have traced a series of unsigned vases back to his workshop or his direct pupils : but they are all amphorae of the ordinary Attic type, while the peculiar innovations in the decorative schemes to which he devoted especial care, have remained almost unheeded by his contemporaries. We have a couple of psykters which most probably imitate models by his hand, and a few amphorae with narrow friezes on the shoulder, though these mostly show no special affinity of style with Amasis. But on the whole one must admit that his efforts have hardly influenced Attic art; while on the other hand these very innovations which he attempted to introduce confirm the supposition of his own foreign origin.

It is a generally accepted opinion that Amasis was one of the numerous artists and artisans whom the rapid development of the commonwealth under the reign of Pisistratus drew to Athens from all countries. Studniczka has supposed him to be a native of Naukratis, as his name naturally points to Egypt. But it is growing more and more apparent that Naukratis was a great trading city, where the wares and merchants of many countries gathered, but not a centre of original commercial or artistic production. Moreover, Loeschcke (Pauly-Wissowa I. 1748, s.v. Amasis) has justly pointed out that towards the middle of the sixth century Attic influence was strong in Naukratis, while not a trace of a Naukratite b.f. style has yet been discovered. He therefore concludes that Amasis came to Athens from eastern Greece, and considers the possibility of Samos being his home. It is impossible at present 
to arrive at any sure conclusion on this point, but I think it may be shown that many peculiarities of Amasis' style connect him with a current of Ionic art, which seems tc have included Samos. To explain this it is necessary to go back beyond the period of actual b.f. painting.

In the most valuable and suggestive account of his excavations in Samos (Aus. ion. und utal. Nelerop.), Dr. Boehlau has shown that the large class of vases hitherto called by the conventional name of 'Fikellura,' and found in large numbers in Rhodes and Daphnae, represents the ceramic industry of Samos in the second half of the seventh century. For the history of archaic pottery this discovery is of the greatest importance; it definitively corroborates the solution which Prof. Loeschcke had long ago proposed for this difficult problem (Athen. Mitth. xxii. 261). It was he who years ago discovered the fine amphora at Altenburg (Boehlau, p. 56) which, with its frieze of grotesque dancing figures, represents the highest development of this class of Samian pottery, and the transition from the archaic to the b.f. style. Other examples of this transitional stage have been found at Daphnae (T'anis ii. Pl. 28), while Boehlau's excavations have as yet touched only poorer parts of the necropolis, with simpler and more archaic Samian vases.

But we can follow the thread farther, with the assistance of a small group of vases found in Italy, which show what the Samian b.f. pottery not yet found on the island must have been. M. Pottier has been the first to draw attention to this group and has proved its Ionic origin in one of his excellent articles on archaic pottery (B.C.H. xvii. 423). I am able to enlarge his list by a few important examples, all of the same shape known as deinos:

1. Louvre E 731. Pottier, Fig. 1, p. 424. Ivy wreath on rim, tongue pattern on shoulder; frieze of dancing Sileni and Maenads, then chain of lotus buds and flowers, and simple rays.

2. Louvre E 804. Pottier, Fig. 2, p. 427. Ivy wreath on rim, herringbone pattern on shoulder; frieze of grotesque dancing youths, then pattern resembling an undulated ribbon.

3. Louvre E 812. Pottier, Fig. 3, p. 428. Undulated line on rim; frieze of warriors, then one of Sirens, and an undulated ribbon.

4. Vienna 215 Masner, Pl. 5. With support. Ivy wreath on rim, tongue-pattern on shoulder; frieze of Sileni dancing, then elaborate zig-zag pattern and double rays.

5. Florence 1839 (quoted by Masner, p. 20). Parallel lines on rim, tongue-pattern on shoulder; frieze of grotesque dancers as on No. 2, then chain of lotus buds and blossoms, and simple rays.

6. Cervetri, Coll. Ruspoli. Frieze of dancers as No. 2, but among them a deinos on a tripod of metal bars, and a man and woman pounding something in a mortar. I have unhappily only had a glimpse of the vase, and noted no details.

7. Brit. Mus. B 46. Lotos chain on rim, tongue-pattern on shoulder; 
banquet scene, seven couches, five servants between them; then frieze of animals and 'polypus'-pattern.

8. Rome, Pal. dei Conservatori 106, with support like No. 4: Broad band of painted scales round body, no figures.

9. Louvre E 810 , quoted by Pottier, p. 430, who doubts its Ionic origin, the men having the Attic shape of the eye. Yet I think the vase belongs to our group. Ivy wreath on rim, burlesque dancers on body, 'polypus' ornament on base.

That all these vases have a common origin is proved by their identity of shape, their many analogies of style and types, in spite of slight individual discrepancies. Nor is the similarity, nay identity, of the grotesque dancers on the deinoi (Nos. 2, 5, 6), and those on the Samian amphorae quoted above, less evident; this analogy is all the more significant, as we find on the deinoi a transition stage of technique, white painted lines and incised lines being used simultaneously for the indication of details. ${ }^{1}$ This peculiarity is another connecting link between the deinoi and the Samian vases, on which incised lines are only once employed; and the similarity of the decorative patterns bears this out. We find on the deinoi the band of lotos buds and flowers peculiar to Samian ware, and a broad band of painted scales as on the Samian amphora Tanis II. Pl. 32, ${ }^{2}$ while at the same time new ornaments appear-the rays, double or single, the ivy wreath, the undulated ribbon afterwards not rare in Attica, the tongue and herring-bone pattern, the so-called 'polypus' 3 an elaborate zig-zag and a curious undulated pattern $($ No. 3,7$)$ to which we revert.

We have thus a clearly defined group of vases, belonging to the earliest b.f. style, and offering the most striking resemblance to that highest development of Samian pottery which directly precedes the actual b.f. style. Of course, without the aid of either inscriptions or local excavations, it would be impossible to prove, and premature to assert that we have here a later phase of Samian art. But certainly these deinoi can serve as examples of what b.f. Samian vases must have been, and must be near akin to them. We may, at any rate, assume them to have been made on one of the Ionic islands, or in a colony on the Asiatic coast; and a similar origin is probable for a small series of amphorae, which offer striking analogies to the deinoi, but appear to be somewhat younger, representing as they do some of the best Ionic examples of developed b.f. pottery.

1 See Pottier p. 425. These white lines appear only on Nos. 1, 7 ; they represent a transitional technique, while the Samian vases use reserved lines for details (the Altenburg vase has a few incised lines), and the Clazomenian sarcophagi only white lines, no incisions.

2 Cf. the Clazomenian sarcophagus Ant. Denkm. i. 45. Ionic amphorae: Berlin 1674, 1885 (B.C.H. xvii. 434 Fig. 7), Arch. Jahrb. i.

E.S.-VOL. XIX.
150 (from Rhodes). Further a Rhodian oinochoe in the Louvre (A 321, Pottier Vuses du Louvre 13). The oldest examples known to me are on Mycenaean vases, e.g. Myl. Vas. x. 62.

3 I take the crescent pattern characteristic of Samian ware to be developed out of the poly. pus, when a foot was added to the vase, just as the rays are derived from a lotos chalice sustaining a vase without a foot; see App. ii. 
The finest vase of this series is the beautiful amphora now in the Marquis of Northampton's collection, and published by Gerhard (A.V. 317-8; Burlington Club Cat. of Greek Ceramic Art, p. 20, 112). To it we may add two amphorae in Munich, Nos. 573 (Wien. Vorl. 1890-1, 12) and 583, published by Lau (Griech. Vas. x. 7, xi. 4) and Studniczka (Arch. Jahrb. v. 142), who has recognised the resemblance and Ionic origin of these three vases. A fourth amphora, Berlin, 1676 (Gerhard A.V.9), though akin to the other three, is slightly different in shape and style.

The stylistic identity of the Northampton vase and Munich 583 (the 'Dolon amphora' according to Studniczka's explanation), is evident in the un.Attic combination of reserved panels on the body with a neck distinct from it, and decorated with two pictures, in the elaborate profiles, copied from metallic models, of neck and foot, in the disposition of the decorative patterns on the vase (bands of ornaments on the rim and foot as on the 'Caeretan hydriae'), in the types of these patterns, such as the lotos chain or the double rays, above all in the quite peculiar and characteristic arrangement of palmettes with little hares among them, which occurs on both vases. As for the third, the so-called 'Io' amphora (Munich 573), it has a different shape, the neck not being distinct from the body, nor the pictures in reserved panels, an equally un-Attic combination (A.V. 9 shows the ordinary Attic shape, only with double rays) ; but the type of the Argos and of the Centaurs' heads, ${ }^{1}$ as well as the Triton with wreath and necklace A.V. 9, connect both with the Northampton amphora; both also have lotos chains and double rays. On the other hand the resemblance to the deinoi quoted above is striking. We find the same type of lotos chain in both groups, also the same ivy-wreath; the double rays appear on deinos No. 4, the plait pattern of the Dolon amphora, though shown by none of our deinoi, is characteristic of Samian ware, while the curious undulated pattern on deinos No. 3 finds its counterpart on the Northampton amphora. ${ }^{2}$ Further, the Sileni on the latter vase, with their bestial faces, mane-like hair, and ribs indicated by incised lines, correspond exactly to the deinoi $1-4 ;{ }^{3}$ while the curious tripod of the Northampton amphora recurs on No. 6 , the Ruspoli deinos. ${ }^{4}$ We may thus safely conclude that this group of amphorae is most nearly related to the deinoi and is contemporaneous or slightly younger.

1 The red nipple surrounded by a circle of white dots is a characteristic Ionic peculiarity. It recurs on a Triton on a fragment of an Ionic cup in Bonn, of the class which Dümmler has wrongly called Pontic.

${ }^{2}$ It is not quite the same; the pattern of the amphora recurs now and then on Ionic vases (e.g. Vienna Hof-Mus. 278); an exact counterpart of the deinos pattern on the fragment of an Ionic pithos from Caria, published Athen. Mitth. xxi. Pl. 6.

3 Two of the Northampton Sileni have horses' hoofs, which ate found on none of our deinoi, but as both these types constantly appear side by side in archaic art, the absence of one of them proves nothing.

${ }^{4}$ For this type of tripod see Savignoni's eareful and accurate study, Mon. ant. vii. 277 ; he quotes the Northampton amphora as the only example of such tripods on painted vases. Besides the Ruspoli deinos, I know another example on Munich 984, an Etruscan hydria copied from an Ionic model, of the class treated by Dümmler Roem. Mitth. iii. 173. 
The connection between the series just examined may appear insufficient, and the documentary evidence fragmentary and incomplete. But it should be remembered that as soon as we leave the well-known track of Attic art we are forced to reconstruct, as best we may, large and important classes now lost to us, from a few stray fragments which chance has spared. And while one cannot be too careful in the inferences drawn from such fragments, yet every effort should be made to retrace their parentage as far as possible. I do not pretend, out of the documents quoted above, to form a continuous chain, but I take them to be links of a broken chain, which if complete would lead down from the archaic pottery of Miletos and Samos, to the fully developed b.f. style of Athens, from the middle of the 7 th to the end of the 6 th century. And to the links which we have quoted we can add a last one, placed near to the end of the chain.

Among the mass of Attic b.f. vases there is a series of amphorae, which form a distinct class by themselves, and were evidently made in the same place, if not by the same hand. Only amphorae have been found, and all in Italy (in fact, with two exceptions, in Etruscan tombs), while not one has to my knowledge till now appeared on Greek soil. $^{1}$ Their queer angular style has earned for these vases the name of the 'affected Tyrrhenian' group. They have hardly been noticed till now; but for a few passing remarks by Jahn (Munich Cat. Einl. clxxi.), Urlichs (Beitr. z. Kunstgesch. 16 f.) and Furtwängler (Münchner. Führer 25), the only archaeologist who has studied them is M. Gsell, who, in his excellent Fouilles de Vulci, has given a list of the examples known to him, a short analysis of their style and type, and the only really faithful reproduction of such an amphora as yet published ( $\mathrm{Pl} .7-8$, p. 502). The list given in my appendix i. contains more than twice as many vases as M. Gsell's, but no doubt several more exist in museums which I have not visited. However, the present material is amply sufficient for an appreciation of the whole class.

The amphora found by M. Gsell at Vulci is important through its having been discovered, as very few examples of this class have been, in excavations conducted with scientific accuracy. It was found in a tomba a camera of a rather archaic type (tombe xlv.; Gsell p. 101, cf. 431 f.), together with a number of bucchero vases of the fully developed type with modelled reliefs some coarse local ware of no chronological importance, and a b.f. lecythus apparently Attic; the tomb had already been plundered, but the objects just described, and the fact that bones of only one body were found in the tomb, allow us to date it with tolerable certainty towards the middle of the 6 th century. This date is confirmed by the few other specimens of our class discovered in circumstances known to us :-

I.-tomba a camera, Orvieto ; Gamurrini Not. d. Sc. 1881, 51. Helbig, Bull. 1881, 267. The ashes of several bodies were found in this tomb, which had also been rifled; any exact chronology of the objects found is thus

1 Dr. Hartwig kindly informs me that not a single fragment of such ware has been found in the 'Perserschutt' on the Acropolis. 
impossible, yet the fact that besides an amphora of our class (No. 30 of our list) only late bucchero and b.f. and severe r.f. Attic vases were found. gives us a valuable terminus post quem.

II.-tomba a camera, Orvieto; Helbig Bull. 1882, 233. Gamurrini Not. d. Sc. 1882, 374. Milani Mus. Ital. III. 209; the contents are now in the Florentine Museum. This tomb, in which the remains of several unburnt bodies were found, had also been plundered. But as it contained a series of vases certainly older than the middle of the 6th century, viz. a panathenaic amphora second only to the Burgon vase in age, a Chalcidian oinochoe, and a Corintho-Attic anfora a colonnette, together with a r.f. kylix signed by Chachrylion, the tomb must evidently have been used for at least a couple of generations. The two affected amphorae discovered here (Nos. 1., 18) probably do not belong to the very oldest deposits of the tomb.

III.-Remains of two amphorae have been found at Adria. One (No. 43) almost intact, was excavated in 1816, 'alla profondità di piedi 20 circa' (Schöne, Mus. Bocchi p. 27), a depth which corresponds to the lowest stratum yet found in Adria. Two small fragments of another amphora (No. 8) were found in 1879 among the remains of a building evidently belonging to Greek settlers of the 6th century, together with numerous b. and r.f. fragments (Not. d. Sc. 1879, p. 96. 101. Pl. III. 47). The fact that no vases older than common Attic b.f. ware have as yet appeared at Adria is again important as a chronological limit.

We have thus gained an approximate date for our amphorae, independently of their style; and the importance of this fact will immediately become apparent. I have already said that all the vases of this class are amphorae, a circumstance in no wise unique in Greek pottery: we can compare the well-known Ionic group of the 'Caeretan hydriae,' in which likewise only one shape of vase occurs. However, the affected amphorae do not all have exactly the same shape, but two distinct fundamental types, each with minor variations :-

I.-The neck is not distinct from the body, the handles tubular, the foot has the shape of an inverted echinus; the whole body is painted black, save for a double row of rays round the base, and two reserved panels, decorated at the top with a chain of hanging lotos blossoms, or of double alternating lotos blossoms and palmettes, such as is constantly employed on archaic Attic amphorae.

a. The shape is identical with that of the Attic b.f. amphora with reserved panels (Walters, Brit. Mus. Cat. ii. Fig. 13).

b. Like $a$, but for the orifice, which instead of being rectangular in profile, is rounded like that of the Attic so-called pelike; the nearest approach to this shape is shown by a Chalcidian amphora in Munich, No. 1106. 
II.-The neck is distinct from the body, the shape thus roughly corresponding to the Attic b.f. amphora with red body (Walters, Fig. 15). However, the shapes both of the body, narrowing below and broader above, and of the neck, which is shorter and smaller, differ from the Attic type, while they closely resemble the Northampton and Dolon amphorae described above. The neck is bordered at each end by a narrow plastic ring, painted red, and imitating the rings of solder on bronze vases; a similar broader ring connects the body with the foot, which is elaborately monlded. The handles are usually composed of three bars, sometimes they are tubular. Some of the plainer specimens have no plastic rings, and the foot is like an inverted echinus. The lower half of the body is painted black, but for a narrow double band of rays round the base and a band of lotos flowers (sometimes missing) above these. On the shoulder, a tongue-pattern, painted alternately black and red, and a chain of hanging lotos blossoms. Below these, a broad frieze of figures. We have three variations of this shape :-

a. Figures painted on each side of the neck (3-4), the shoulder frieze divided into two pictures, of one to two figures each, by a very elaborate and beautiful palmette ornament, under the handles.

b. Neck as $a$, but the shoulder frieze is continuous, the figures under the handles being painted smaller. The large figures next to the handles are often partially covered by them, thus showing that the vase was painted before the handles were attached to it. The base of the handles is surrounded by a painted tongue-pattern ending in volutes. In two cases, Nos. 20, 21, the lower ends of the handles are flattened and decorated with small figures in reserved square panels.

c. Body as $b$, but the neck instead of figures has the double chain of lotus flowers and palmettes addorsed, which is the constant decoration for the neck of Attic b.f. amphorae with red body.

Within the limits of these variations the execution of all our examples is identically alike. The clay is a fine warm orange colour, rather less reddish than ordinary Attic clay, the glaze black aud brilliant, never unequally fired or discoloured. White and red are freely used for details, also incised lines drawn with great delicacy and precision. The execution is careful and accurate in the extreme, the smallest details of decoration recur with unfailing regularity, nowhere do we find the individual peculiarities and variations frequent in other classes of pottery. At the same time, the excellence of technical execution and the sure, easy, faultless drawing; are most remarkable. I have not noticed a single case either of careless omission or of mistaken rendering of any detail, nor of those blunders in anatomy which M. Pottier, in a recent admirable article (Rev. d. étud. grecques 1898, 355), shows to be due to the use of silhouettes in vase painting. There is no class of vases more correct, faultless and accurate in its minutest details, and the easy excellence resulting from a long tradition is evident everywhere. But while the affected amphorae represent an exceedingly high development of ceramic art, they are at 
the same time not only lifeless, angularly stiff, and almost grotesque in style, but strangely monotonous and poor in the range of their types and subjects. Each figure is executed with the minutest care, delicate ornamentation is lavished on robes, armours and arms; but only a few ever-recurring figures make up the few dull scenes repeated again and again on these vases.

If we examine first the decorative patterns, we find the double row of rays to be absolutely constant and characteristic of all examples, throughout the different variations of shape and decoration. The amphorae of type I. have in addition a chain of lotos flowers or an an alternate lotos and palmette chain, both frequent in Attic art and particularly in Amasis' circle : we find the latter pattern constantly on the jugs signed by him, while the chain of lotos flowers is characteristic of that group of amphorae which we have attributed to his workshop. Only here the flowers point upwards, while on the affected amphorae they are invariably drawn hanging downwards, a peculiarity which I have noticed upon hardly any Attic vases, but on a few Ionic amphorae.

On the amphorae of type II. the lotos chain above the rays, the tonguepattern and lotos chain on the shoulder, are equally unfailing ornaments. Their delicate thin drawing distinguishes them from the similar patterns on ordinary Attic amphorae with red body. Only the double lotos and palmette chain on the neck of type II $c$ is quite Attic in style. For the peculiar practice of reserving small panels at the base of the handles (Nos. 20, 21 of our list) I only know one Attic analogy, the little hares on the handles of a r.f. amphora by Andokides (Berlin 2159. Gerhard, Trinkschalen 19-20). However, Andokides was very probably much influenced by foreign models, and we find a similar, if not identical, scheme of decoration in the gorgoneia on the handles of the beautiful amphora published by Pottier (B.C.H. xvii. 439-40, Fig. 10-12) which I am inclined to think of Ionic workmanship. It is important that both the chain of lotos flowers round the inner lip of this vase, and the choice of subjects for the shoulder frieze-man on folding chair, and youthful rider, both surrounded by men in long robes dotted with rosettes, lizards in the field-entirely resemble the affected vases, though their style is different.

Returning to the decoration of the latter, we have still to examine its most important elements. The tongue-pattern, which almost invariably surrounds the base of the handles of type II., is evidently an imitation of metal vessels, where such a pattern, attached to the end of the handles, covered the place where these were soldered to the body. This detail appears on no b.f. Attic vase, while it is quite characteristic of the 'Caeretan hydriae' quoted above, and thus probably of Ionic origin. ${ }^{1}$ And the same

1 Of the practice of painting the vase with so little regard to the handles, that their ends partially cover some of the figures, an interesting example is offered by a fine bucchero hydria of fully developed style, in the Museo Municipale at Orvieto: on this vase, which belongs to a class copied directly from Ionic bronze models, the reliefs have been stamped on before the addition of the handles, one of which accordingly covers all but the legs of a male figure. A tongue- or egg-pattern round the base of handles is frequent in later r.f. art. 
applies to the beautiful palmette ornament painted under the handles of type II $a$ (the rarest type, of which I know only four examples). Savignoni, in his valuable article on Ionic tripods, has been the first to recognize the importance of this ornament, and has published one of our amphorae (No. 14, Mon. ant. vii. 342, Fig. 22); as he justly explains, these palmettes imitate the elaborate decoration of Ionic and Chalcidian metal vases. We still possess quite a characteristic example in the beautiful bronze handle in Berlin, published Arch. An\%. 1893, 97. From similar prototypes the palmettes on our amphorae are derived, though they are probably not copied directly from metallic, but from other painted vases; and an idea of these models is given by the strikingly similar ornaments on the Northampton and Dolon amphorae, which are already connected with the affected series through their shape and scheme of decoration. In Attica again the most similar, if considerably simpler ornament is the palmette arrangement under the handle of the amphora by Amasis in Paris; while the same master, in his amphora at Naples, gives an example of the continuous friezes with smaller figures under the handles, which are peculiar to the affected amphorae and almost unknown in Attic art.

Thus at every step we discover discrepancies between the affected group and the ordinary b.f. ware. Another peculiarity of the former is that very narrow fillets and small pieces of stuff are frequently scattered among the figures (Nos. 4, 6, 8 bis, 21, and 11, where an aryballos and a flute-case are added): it is the old horror vacui which in Milesian and Corinthian art fills the field with ornaments, and which the Attic developed b.f. style had left far behind. The same applies to the animals, which are often painted on the affected amphorae purely as decorative elements. Lizards run across the field $(1,4,6)$, foxes or deer hang dead against the wall $(4,6,12,41)$, birds fly above the figures very frequently, now and then with snakes in their beaks, as on Chalcidian and Corinthian vases $(17,21,29)$. Dogs accompanying their masters are very frequent, but of course neither merely decorative nor in any way characteristic, and the same applies to the does standing beside men $(11,23,25,28,37,43)$. Other animals occur occasionally, swans $(12,24)$, a hare (4), cock (39), ram and goat (32), eagle (8 bis), boar (21), also a siren (12), a sphinx (23), and winged horses (18, 19, 20, 24; with rider, 21); while in one case we find the group of two panthers attacking a doe $(39=$ Mus. Gregor. ii. 31), its Ionic origin being shown most clearly by the female sex of the panthers. ${ }^{1}$ But the most important type of all-the animals appearing in connection with human figures will be treated below-is the bird with a griffin's head, which appears on No. 37 (Micali, Storia 77). In the Strena Helbigiana, to be published shortly, I have traced the development of this monster, and shown that it was introduced into Greece by the Ionians, and was practically unknown in Attic art. Not a single example of it is found on ordinary b.f. ware, and the type figured on our

${ }^{1}$ Such female animals, mostly with very large udders, are a favourite subject of certain Ionic and Etruscan series, 
amphora, resembling more a pea-hen than a griffin, yet proved to be that monster by its recurved wings, has till now been found only on later Corinthian vases, though it is an ancient oriental creation.

Thus we find not only a number of purely decorative animals, such as the Attic painters had long since discarded, but also types like the female panthers killing a doe, or the bird with the griffin's head, which are foreign to Attic art, and reminiscences of ancient Ionic tradition. We find a combination of the most highly developed and brilliant b.f. technique, with a preference for archaic elements of decoration, a faithful preserving of antiquated types, which is in marked contrast to the ordinary Attic vase painting, so strongly susceptible to new foreign influences and individual innovations. If we proceed to examine the scenes represented on this peculiar series, we again find the same contrasts and discrepancies. It is surprising how few types, hardly varied, constitute the entire stock of such a large number of vases.

The most important and frequent are the male figures: we find, first, a naked man or youth, usually gesticulating in an affected manner, never ithyphallic; his breasts, and sometimes his beard and hair, are painted red, the latter, bound by a fillet or wreath of beads, either hangs down his back or is tied up in a curious loop peculiar to this class; sometimes he wears a similar wreath or $\pi \in \rho i a \mu \mu a$ round his arm or across his breast.

The same type then appears with a short chlamys, either hanging over one arm or over both shoulders, with slight variations in the folds; it is decorated with red dots, and rosettes of white points with a red centre, and has tassels on its corners, but no fringes.

The third frequent male type is a man-only once a youth, No. 2wearing a long chiton, mostly red or black with red dots, and an himation over it embroidered like the chlamys of the preceding type. This embroidery and the tassels appear quite regularly. Both arms are always visible, a peculiarity of this class, while on ordinary b.f. vases such men usually have one arm wrapped up in their himation. The long-robed man, though he may gesticulate with his hands, always stands quietly, leaning very often on a staff or lance, or holding a wreath, and usually wearing sandals. This figure is easily changed into a god by placing attributes in his hands: a fish $(4,11,12,21)$, a fish and trident (21), a kantharos and vine branch (see below); he also appears seated on a chair or throne, a variation which we shall examine below.

Besides these three most frequent male types we occasionally find another, clad in a short chiton, mostly red, cut off straight at the loins, always showing the phallos, and a chlamys round his shoulders. This figure is rare $(23,28,30)$; it occasionally wears a nebris strapped across the chiton $(34,39)$, and in this form is used both for Hermes (see below), by the addition of winged shoes, pilos and kerykeion, and for the frequent type of the warrior. The latter wears a metal cuirass over his chiton and nebris, a Corinthian helmet, and greaves, and carries a sword, lance and shield, usually a Boeotian one, decorated with a large snake springing from its centre, an evident 
imitation of metal work. The snake is occasionally replaced by a Silenus' mask $(12,21)$ or a flying eagle $(30,31$, round shields), a frequent episemon on Chalcidian vases. All the metallic parts of the armour are ornamented with white dots along the outlines, and the cuirasses show the double volute on the breast which is so frequent on b.f. vases.

The same male type, clad in a short chiton, is further employed for the horseman (see below), and for the curious winged man who occasionally stands among other men, without any apparent significance $(5,16$ bis, 25,39 , 42); this figure, with two spread and two recurved wings growing from his shoulders, and winged shoes on his feet, is one of the most peculiar and characteristic types of the affected class. Such winged figures are a favourite subject of Ionic artists, who copied them from Oriental models, while in Attica they are a rare foreign importation. It is important to note that an exactly similar double pair of wings is worn by the Gorgon on a jug signed by Amasis, and by the winged youth and the Artemis on two of the amphorae we attributed to his workshop: another of the numerous resemblances between that artist and the affected vases, and another proof of the influence of Ionic art on buth.

The types examined above constitute the whole stock of male figures on our amphorae; the little boys who occasionally appear $(17,20,22,41)$ are simply reductions of the nude youth, and have no special significance, with the exception of 41 , where a long-robed man brings such a boy to another man standing before a tree, probably a reminiscence of the well-known scene of Peleus entrusting the infant Achilles to Chiron.

Women are rare on the affected vases, which show quite a peculiar preference for men. Their flesh is white, the eye usually incised, but occasionally painted in red outline on white ground, a technique which I have noticed on some of the amphorae attributed above to Amasis' school. There is one

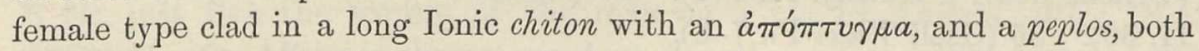
embroidered exactly like the men's dresses; she wears sandals, and usually holds the edge of her peplos before her face, in the scheme so frequent on Chalcidian and Corinthian vases, while it is discarded by the Attic artists of the developed b.f. style $(1,3,6,12,27,28,34,37,42)$; another detail in which the affected vases have preserved an archaic tradition long given up in their time. The same woman appears holding a lance (4) or a fish (11) in her hand, or seated on a throne (4), probably as a goddess, just as similar attributes make gods out of long-robed men; further, as Deianira, seated on the Centaur's back (20, 42).

Besides this ordinary female type we find the Maenad, in a shorter chiton with an ámó $\pi \tau v \gamma \mu a$ of curious cut, for which the nearest analogies are again offered by the Maenads on Amasis' vases; just as most of these, she wears no nebris, and is always found in company with a Silenus, either following Dionysos (29) or under the handles of the amphora, dividing two different scenes $(30,31,34$, where an ordinary man is substituted for the Silenus). The Silenus, one of the most important types of our vases, is always ithyphallic, with human feet, not hoofs, as is natural in this period, but with 
a horse's ears and tail and a bestial expression; the face is rarely drawn in profile (3), almost always in a front view (3, 29, 30, 31, 38 ?) unusual in Attic art, while it closely resembles the Silenus' head on the Würzburg amphora by Amasis. We have also some Ionic examples of this first attempt at a perspective of the face.

Having thus analysed the types used on the affected vases we must now examine the scenes which they compose. It has already been said that the technical perfection of these amphorae forms a striking contrast to their poverty and monotony in the choice of subjects. Not only are the scenes on either side of each vase usually almost identically the same, but the artist has followed the invariable principle of composing each scene out of two central figures, the principal one always turned to the right, surrounded on either side by one or two spectators, who are usually meaningless and superfluous. The few exceptions to this rule, necessitated mostly by want of space, only serve to confirm it (14-16 bis, $23,25,32,36)$. The monotony and lifelessness of such a system of decoration is obvious, and rendered more striking by the small number and scanty interest of the scenes represented.

I.-Two male figures of the types discussed above-mostly naked or with a chlamys -in animated discourse, their gestures affected and very slightly varied, between two to four spectators. Many of these scenes, which are by far the most frequent of all-more than forty examples are found on the fortysix vases of our list-are quite devoid of meaning, others have a paederastic significance, emphasised in some cases by gifts offered by one of the central figures to the other : a cock $(7,36),{ }^{1}$ a hare (28), a cup and perhaps a doe (43), an aryballos (17). It is worthy of note that the men are never ithyphallic, and that no women appear in these scenes. In one case the scene is varied by one of the youths holding a diskos (20). Published examples: 19 (Urlichs Beitr. z. Kunstg. Pl. 1-6). 23 (Micali Storia 75-6). 26 (Mus. Greg. II. 30). 35 (Gsell Vulci Pl. 7-8).

II.-Warrior putting on his armour; he is fastening his second greave, while helmet and shield either lie at his feet or are held by a man or woman opposite him. On either side one or two spectators: $6 \mathrm{~A} .11 \mathrm{~A} .13 \mathrm{~A} .14$ neck B. 41 B.

III.-Warrior fully armed talking to a man or woman-on $13 \mathrm{~B}$ and $21 \mathrm{~B}$ to Hermes - with spectators on either side; on 14, 16 bis there are no spectators for lack of space. This scene usually occurs on the reverse of vases with Scene II. on the obverse (6 B. 11 B. 13 B), but also in other cases (12 AB. 14. AB. 16 bis AB. $21 \mathrm{AB}$. $23 \mathrm{AB}=$ Micali Storia 75-6), and warriors are occasionally found among the spectators (21 AB. $28 \mathrm{~B}$ ).

IV.-Two warriors fighting with lances; without spectators $15 \mathrm{AB}$, for lack of space; with spectators $30 \mathrm{AB}$. $31 \mathrm{AB}$. $36 \mathrm{~A}$. $37 \mathrm{~B}$ (Micali Storia

1 On a small b.f. amphora in the Museo Gregoriano (ii. 44) of rather a peculiar shape,we find a similar paederastic scene with cocks offered as gifts; some of the men wear $\pi \in \rho \iota{ }^{\prime} \mu$ $\mu \alpha \tau a$ like those on the affected vases. 
77-8). 42 B (Gerhard A.V. 117). On $33 \mathrm{AB}$ (Micali Mon. in. 44. 2) a longrobed man stands between the two warriors, in the scheme usual for the combat between Herakles and Kyknos.

V.-A rider, almost always youthful and holding a second horse ; without spectators, for lack of space, $16 \mathrm{AB}$; usually one or two spectators on either side, with one of whom the horseman is conversing: $17 \mathrm{~A} .19 \mathrm{~A}$ (Urlichs Beitr. 2. Kunstg. Pl. 1-6). 20 B. 24 A. 34 AB. 43 A.-single riders under handles 21, 26, 41. On $21 \mathrm{~B}$ a horseman, bearded in this case, stands between Hermes and Poseidon, while on $28 \mathrm{~B}$ we find a reminiscence of the well-known Troilos myth: a long-robed man (Priam) holding a sceptre, is seated on a chair opposite the youthful rider, whom a warrior (Achilles) pursues; while to the left stands a woman, holding not the traditional hydria of Polyxena, but an oinochoe which is entirely out of place, and shows that the artist was hardly conscious of the myth he copied from memory or from some model.

VI.-Dionysos with kantharos and a large vine branch in his hand, longrobed and crowned with vine leaves (on 37A he has winged shoes) stands opposite a man in the same dress $(2 \mathrm{~A}, 3 \mathrm{~A}, 32 \mathrm{~B}, 38 \mathrm{AB})$; this man is occasionally characterised as a god by his attributes: fish and lance, perhaps Nereus, 4A; a doe beside him, probably Apollo, 28A, 37B (Micali Storia 78); or he is replaced by a naked man $(29 \mathrm{AB})$ or a woman (perhaps Ariadne, $3 \mathrm{~B})$. The spectators are men or Sileni $(2 \mathrm{~A}, 3 \mathrm{AB}, 29 \mathrm{AB}, 38 \mathrm{AB})$, only in one case a Maenad among them (29AB). Sileni and Maenads under handles, without Dionysos, 30, 31.

VII.-A long-robed man seated on a folding chair, or more frequently on a throne, holding a lance or sceptre crowned sometimes with an animal's head (griffin 2B, with open beak and two knobs on it; pegasos $1 \mathrm{AB}$; ram 8 bis, just like the sceptre of the man on a jug by Amasis, Wien. Vorl. $1889,4)$. On $1 \mathrm{~B}$ he is characterised as Zeus by a large thunderbolt in his right hand. Before him Hermes, in the garb described above, is walking away, his head turned back to speak to 'Zeus.' On either side one or two spectators: $1 \mathrm{AB}, 2 \mathrm{~B}, 8$ bis, 16 neck $\mathrm{AB}, 17 \mathrm{~B}, 18 \mathrm{AB}, 19 \mathrm{~B}, 24 \mathrm{~B}, 39 \mathrm{~A}$. Occasionally Hermes is replaced by a long-robed (16B, 16 bis neck AB, 24A) or a winged man (39B, where, however, a man with a short chiton and nebris, but without the other attributes of Hermes, is standing behind 'Zeus'); while on $4 \mathrm{~B}$ a woman, holding a wreath and a lotos flower, sits on the throne in' Zeus' stead. The back of the throne terminates in a swan's head, its traverse usually bears a small animal, a pegasos (1B), lion (2B, 19B), sphinx (4B, a hare under the throne), panther (17B); this is an ancient oriental feature, which we find on Assyrian reliefs e.g. Botta-Flandin Mon. de Nineveh I. 18, Rawlinson Five Great Monarchies I ${ }^{4}$ 394), and is a most important sign of strong Ionic influence on the affected vases; ${ }^{1}$ in Attica we occasionally 
find a similar throne with the back ending in a swan's head (Mon: $d$. Inst. VI. 56), and once also a sphinx sitting under it, not on the traverse (Gerhard A.V. 1 : back of throne ending in a lion's head). Both these vases are archaic and represent the birth of Athena, while our scene seems a reminiscence of a myth in which Hermes appears as the messenger of Zeus. But when we consider the thoughtless manner in which myths are reproduced on the affected amphorae, we shall hesitate to attribute a special significance to this scene, as Urlichs (Beitr. $z$. Kunstg. p. 16, pl. 1-6) has done in publishing No. 19.-Hermes alone, among other men, 13B, 21AB, 36B.

These scenes really constitute the whole stock of our vases. A few other subjects occur in isolated examples: Theseus killing the Minotaur with his lance (5A), a unique treatment of this myth; Herakles wrestling with the lion, also drawn in an unusual way, ${ }^{1}$ Herakles pursuing Nessos $(42=$ Gerhard $A . V .118$, the ordinary type; on $20 \mathrm{~A}$ Herakles is replaced by an ordinary warrior). On $32 \mathrm{~A}$ a procession is moving to r., towards a burning altar placed under one handle: six long-robed men, three of them carrying myrtle branches, one an oinochoe, another an oinochoe and a flat plate with cakes on his head, while another plays the flute; a ram is walking behind the second man. This vase, figured by Micali, Mon. in. 44, 1, is of the greatest importance, as the subject, even in details like the peculiar plate with cakes, the oinochoe and myrtle branches, is almost identical with that of one of the amphorae of Amasis' school quoted above (p. 138, Adamek, fig. 8). On 36B we find a similar scene, only the altar and the offerings of the men are missing, and Hermes appears among them; on 21B Poseidon is standing to left, while a procession of five men moves towards him: first Hermes, with a $\kappa i \beta \iota \iota \varsigma$ over his arm, his head turned back and striding across a burning altar-an attempt at perspective, the altar being evidently supposed to stand in front of him; behind him two warriors and two long-robed men with lance and fish, alternating in rapid motion. All these are simply scenes of sacrifice or worship, without any special mythological significance.

A last and one of the most important features of the affected series has still to be examined: while the Attic potters usually show a marked preference for inscriptions, lavishing them on human beings and even on inanimate objects, the affected vases, conforming herein also to Ionic custom, carefully avoid all inscriptions. ${ }^{2}$ I know only two exceptions to this rule,

1 Under the handles of 19 (Urlichs l.c. Pl. 2) and 20 : Herakles, clad only in a short chiton, seizes the lion by both front paws and pulls him towards himself. This is not the oldest type, where he attacks the animal with his sword (Roscher, Lexiton d. Mylh. 2196).

$2 \mathrm{On}$ all the principal Ionic classes, the Caeretan, Samian, pseudo-Pontic, etc., inscriptions are entirely missing. 
NOTES ON AMASIS AND IONIC BLACK-FIGURED POTTERY். 157

No. 11 (Louvre F 23), on which meaningless signs imitating letters are painted between the figures (Fig. 2), and No. 12 (Louvre F 24). Of the latter vase I am able to publish drawings by M. Devillard (Fig. 3-4), thanks

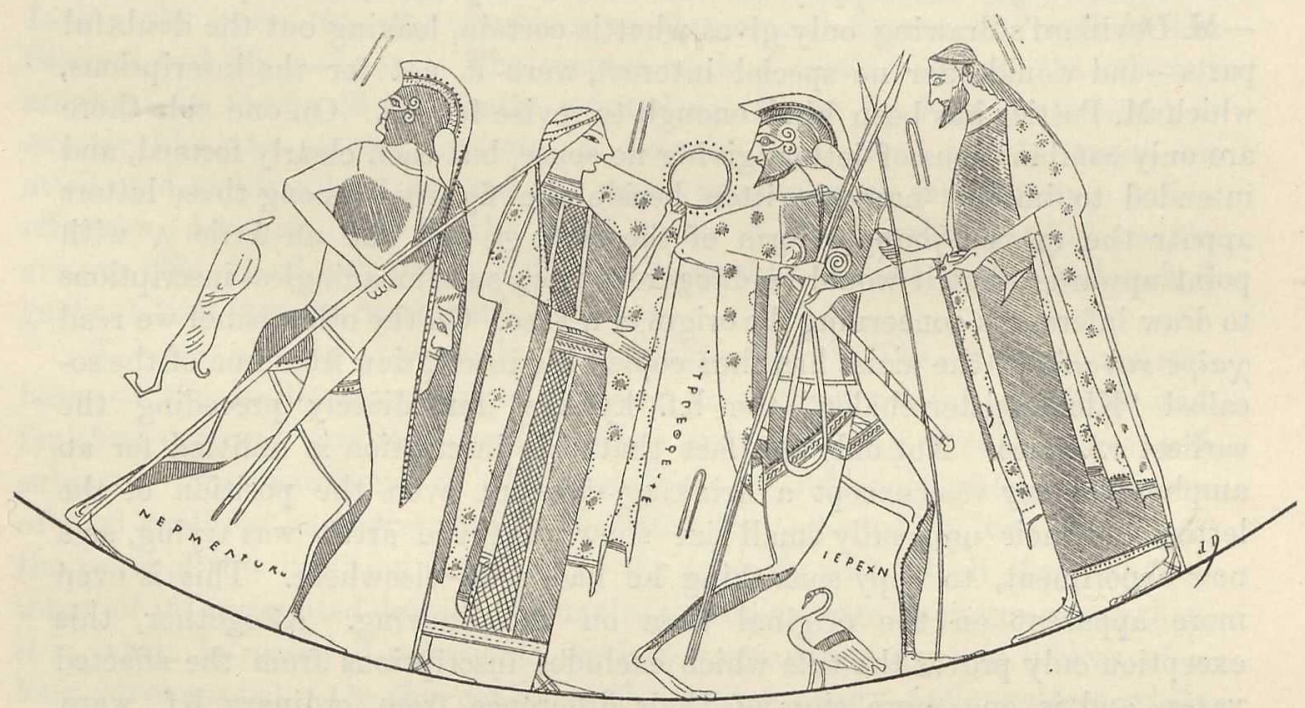

FIG. 3.

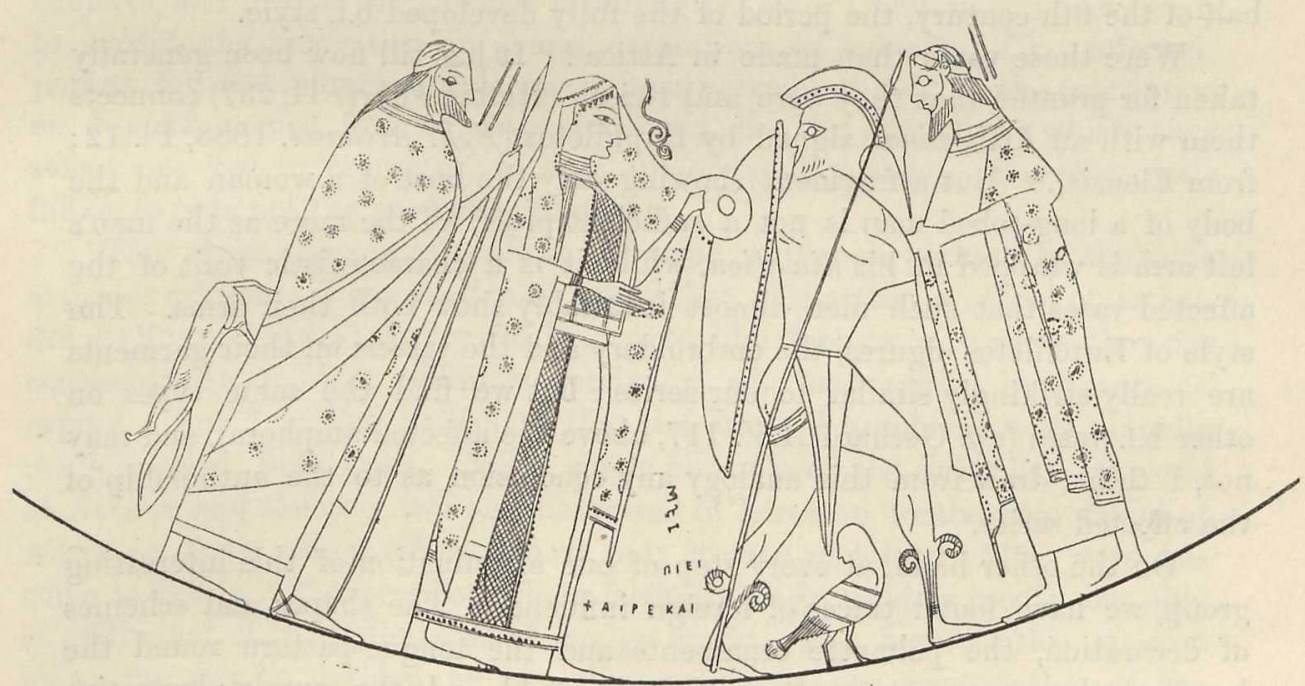

FIG. 4.

to the generous kindness of M. Pottier, who has himself devoted particular attention to the same series and will soon, I hope, give us the results of his researches. I am glad here to express my gratitude for his unsurpassed 
liberality. On both sides of the vase we find the same scene: a woman offering a wreath to a departing warrior, between two spectators, long-robed men on one panel, a warrior and a man holding fish and lance on the other. A dead fox hangs against the wall, while a swan and a siren stand between the warrior's legs. Unhappily the vase is in a very bad state of preservation - M. Devillard's drawing only gives what is certain, leaving out the doubtful parts-and would offer no special interest, were it not for the inscriptions, which M. Pottier has been kind enough to revise for me. On one side there are only combinations of letters giving no sense, but each clearly formed, and intended to imitate names written beside the figures: among these letters appear the $Q$, the younger form of the theta $\odot$, and the un-Attic $\wedge$ with point upwards; but it would be dangerous from such meaningless inscriptions to draw inferences concerning the origin of a vase. On the other panel we read $\chi a i \rho \epsilon \kappa a i \pi i^{\prime} \iota ;^{1}$ the artist has thus copied his inscription from one of the socalled 'Kleinmeisterschalen,' the b.f. kylikes immediately preceding the earliest r.f. ones. Not only the fact that this inscription is unfitted for an amphora, or any vase except a drinking cup, but even the position of the letters and their unusually small size show that the artist was trying, as a new experiment, to copy something he had seen elsewhere. This is even more apparent on the original than on the drawing. Altogether, this exception only proves the rule which excludes inscriptions from the affected vases, and is one more sign of their difference from ordinary b.f. ware. Moreover, the fact that a b.f. kylix of such late type served as a model for the inscription, proves again that the affected amphorae belong to the second half of the 6th century, the period of the fully developed b.f. style.

Were these vases then made in Attica? It has till now been generally taken for granted that they were, and Reisch (Helbig Führer II, 237) connects them with an Attic pinax signed by Euphiletos (Eph. Archaeol. 1888, Pl. 12; from Eleusis). ${ }^{2} \quad$ But a fragment showing only the bust of a woman and the body of a long-robed man is not a sufficient proof, all the more as the man's left arm is wrapped in his himation, while it is a characteristic trait of the affected vases that such men almost invariably show both their arms. The style of Euphiletos' figures, the embroidery and the tassels on their garments are really strikingly similar to our series; but we find the same types on other b.f. vases (e.g. Gerhard A.V. 117, above the affected amphora), and may not, I think, draw from this analogy any conclusion as to the authorship of the affected series.

On the other hand, at every step of our examination of this interesting group, we have found traces of foreign influence. The shapes and schemes of decoration, the palmette ornaments and the tongue-pattern round the handles, the ornaments scattered in the field and the purely decorative animals, the $\pi є \rho \imath a ́ \mu \mu a \tau a$ of the men and the winged figures, the oriental

1 The three letters above this, written vertically, have no sense, nor any connexion with the lower inscription.
2 R. Delbrïck, Linienperspective in d. Gr. Kunst, Bonn 1899 p. 10, 12, quotes nr. 42 (Gerhard $A, V, 118$ ) as an Ionic vase. 
type of the throne, are all distinctly un-Attic peculiarities, and connect our amphorae with Ionic art, and principally with those series for which we have collected the rather scanty documentary evidence above. On Attic soil, the most striking analogies to the affected vases are found in the work of Amasis, and in those very peculiarities of his style which again point to Ionia: the palmettes, the double rays, the winged figures, the type of the Silenus and Maenad, etc. The sceptre with a ram's head on the affected amphora in Gotha ( 8 bis, kindly pointed out to me by Prof. Loeschcke) is exactly like the sceptre on one of Amasis' jugs. And on the vases we attributed to his school we find the same procession of men bearing votive offerings (Adamek, Fig. 8), the same scene of the warrior putting on his armour (No. 15 of our list, p. 139), the same four-winged youth and naked gesticulating men, as on the affected vases.

I have already repeatedly drawn attention to the strange contrast between the brilliant technique of these vases, their careful, elaborate and faultless drawing, and the small number and monotony of their types and subjects. Such excellence of workmanship is possible only when generations of good tradition have prepared it; and that the 'affected' potters recognised the value of this tradition is proved by the tenacity with which they cling to many of its antiquated details. Thus their work appears far more archaic than it is, while in reality it represents the last stage, grown dry and lifeless, of a long development. On the contrary, the contemporary Attic potters, while they devote less and less care to the technical execution of their vases, seem chiefly anxious to make them interesting by a varied range of types and subjects, and instead of jealously retaining an older tradition, are ever ready to accept any innovation in shape, decoration, or subject. The 'affected' potters felt the influence of Attic art, as is proved not only by the inscription on No. 12, copied from an Athenian kylix, but by the myths which they sometimes try to represent, without understanding them. But the Attic influence was not the predominating one.

That these vases were made in the same workshop, perhaps by the same artist, is evident. I am unable to prove that this artist, or school of artists, did not live at Athens; if they did, they were, like Amasis, with whom they are connected by so many affinities, foreigners who had settled in Pisistratos' capital. But I incline to believe that the affected amphorae were actually made in some Ionic town. Not a single example of the series has appeared at Athens, and the only two not discovered in Etruscan tombs were found at Adria, an Ionic colony where almost only coarser and later Attic ware has come to light. Of course both these facts cannot be used as proofs, but only as additional slight indications of foreign origin. But, however this question may some day be decided by new discoveries, for our appreciation of the affected vases the result remains the same. ${ }^{1}$ We have tried to reconstruct an important branch of Ionic art, in which all stress is laid on excellence of techrical execution and delicate ornamentation, while the figures are stiff and

1 Attic vases have always been largely exnatural that their influence should have made ported to all other parts of Greece and it is but

itself felt : while the Attic potters do not seem to 
angular, the range of types and subjects restricted and monotonous, just the reverse of that other great Ionic branch, comprising the 'Caeretan,' pseudo-Pontic and other series, with its somewhat coarser execution, large, fleshy figures, full of life and movement, and its varied stock of originally and vigorously treated myths.

To the former branch we can ascribe the Samian ware, the Clazomenian sarcophagi, the Ionic deinoi, and the group of amphorae discussed above (p. 146): and its last shoots, already ingrafted with Attic art, are Amasis and the affected vases.

George Karo.

\section{APPENDIX I.}

List of AfFected Amphorae. The different shapes are discussed above, p. 148 ; the scenes, here only quoted by their numbers, p. 154.1

\section{I.-Amphorae with reserved panels.}

(a) The usual Attic shape:-

1 (N). Florence, Sala di Volsinii. Orvieto (see above p. 148). A. Scene VII.: throne with pegasos on traverse, behind it a luterion. Zeus holds a thunderbolt and a sceptre with the forepart of a pegasos. B. Scene VII.: 'Zeus' on folding chair, holding only sceptre : behind him, a lizard in the field. Among the spectators, two women.

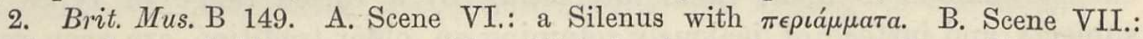
'Zeus' on throne, holding sceptre with griffin's head: on traverse, a lion. Youth with

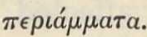

3 (Q). Orvieto, Mus. Munic. 167. A. Scene VI.: 2 Sileni. B. Scene VI. : a woman opposite Dionysos, 2 Sileni.

4. Corneto, Museo Bruschi. A. Scene VI.: opposite Dionysos man holding a fish : fox hanging against the wall. B. Scene VII.: woman on throne, holding wreath and lotos blossom: sphinx on traverse, hare under throne. Among spectators woman with lance, man with fish and lance. Fillets, pieces of stuff, and a lizard in the field on either side.

5. Munich 74. A. Theseus, clad in short chiton and chlamys, his sword hanging by a belt, drives his lance into the Minotaur's neck. B. winged man among spectators.

6. Louvre F 27. A. Scene II. B. Scene III.: woman opposite warrior, a dog beside him. On either side, a fox against the wall, lizard, bird, fillets in the field.

7. Bologna, Museo civico. A. Scene I.: cock offered as gift. Two dogs.

8. Adria, Museo civico A 47. Not. d. Sc. 1879, Pl. III., pp. 96, 101. Two small fragments, each the left upper corner of a panel. A. upper part of two men; B. of one man, to $\mathrm{r}$.

8 bis. Gotha (noted by Prof. Loeschcke). A. Scene VII.: 'Zeus' on folding chair, holding sceptre with ram's head, before him an eagle. Hermes' keryleion ends in snakes' heads.

have modified their style to please their foreign customers. Among the vases found in the recent excavations in Cyprus conducted by the British Museum, I have noted an amphora and an oinochoe, both of the typical Cypriote shape, but made at Athens, evidently for clients in
Cyprus. Yet their style is purely Attic, without any attempt at accommodation to foreign tastes.

1 The capital letters in brackets are those of Gsell's list of affected vases (Fouilles de Vulci, $502)$. 


\section{NOTES ON AMASIS AND IONIC BLACK-FIGURED POTTERY. 161}

(b) Orifice rounded, otherwise like $a$ :-

9. Brit. Mus. B 150. A. = B. Scene I. MXА scratched on the bottom.

10. Louvre F 22. A. = B. Scene I.

11. Louvre F 23. A. Scene II. : long-robed man with fish. B. Scene III.: woman with fish and wreath, man with fish ; dog beside warrior, youth with doe. In the field, on either side, fillets, pieces of stuff, a flute-case (A. an aryballos), and meaningless signs (see above, Fig. 1).

12. Lowvre F. 24. Published above, Figs. 3, 4 . warrior.

13. Parma, Museo archeologico. A. Scene II., B. Scene III.: Hermes opposite the

\section{II.-Amphorae with red body, and distinct neck.}

(a) Figures on neck, palmettes below handles:-

14 (L). Florence, 1818. Neck: A. Scene I., B. Scene II. Body : A. = B. Scene III.: warrior opposite long-robed man, without spectators. Savignoni, Mon. ant. vii. 342, Fig. 22 (side view).

15 (P bis). Orvieto, Mus. Munic. 270. Neck missing. Body: A.=B. Scene IV.: no spectators.

16. Munich, 72. Neck : A. Scene VII.: folding chair. B. the same, but long-robed

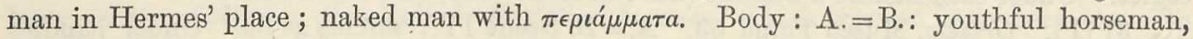
no spectators.

16 bis. Naples, 2744. Neck: A. long-robed man on chair between two others. B. the same, but one of the standing men wears four wings. Body: $A=B$. warrior to $r$. shield seen from inside), without spectators.

(b) Figures on neck, continuous frieze on body :-

17 (M). Florence, 1788. Neck: A.=B. Scene I. aryballos as gift, on B. Body: A. Scene V.; bird with snake in beak. B. Scene VII.: panther on traverse of throne, behind it a small boy. Savignoni, Mon. ant. vii. 334, Fig. 20. Under handles gesticulating figures.

18. Florence, Sala di Volsinii (see above, p. 148). Orvieto. Neck: A.=B. Scene I. Body : A. =B. Scene VII. Under handles pegasi.

19 (K). Würzburg, 257. Urlichs, Beitr. z. Kunstg., Pls. 1-6. Neck: A.=B. Scene I. Body : A. Scene V.; bird flying. B. Scene VII.: lion on traverse of throne. Under one handle Herakles seizing lion, under the other a pegasos, above which a bird flying.

20 (E bis). Munich, 84. Vulci. Neck: A. fragmentary, probably Scene I. B. Scene I.: man holding diskos. Body: A. Nessos carrying off Deianira, pursued by a warrior; woman among spectators; flying bird. B. Scene V.: one spectator holds little boy. Under one handle youth wearing chlamys, under the other remains of a horse. Handles flattened at base, with little panels : Herakles and lion.

21. Louvre F 19. Neck: A. Scene I., B. Scene III.: on either side a folding chair : three men wear $\pi \epsilon \rho$ tá $\mu \mu a \tau a . ~ B o d y:$ A. Scene V.: Hermes, Poseidon and a warrior among the spectators; two dogs. Bird flying, with snake in its beak. B. Poseidon to l., behind

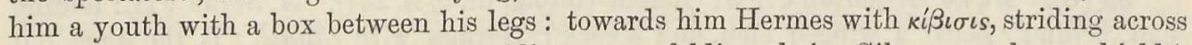
a burning altar, then two warriors (striding across folding chairs, Silenus-masks on shields) and two long-robed men with lance and fish, alternating. Below handles: (a) rider galloping, folding chair with bird above it, long-robed little man. (b) boar rearing and rider on winged horse. Small panels at base of handles : $(a)$ rider on winged horse and naked man. (b) rider galloping and long-robed man with lance. No tongue-pattern round base of handles. On neck and body, fillets and pieces of stuff in the field.

22. Louvre F 20. Neck: A.=B. Scene I. Body: A.=B. Scene I. One man leads a little boy. Under handles small men, and on one side a column bearing a great bowl.

23 (H). Brit. Mus. B 152. Neck: A.=B. Scene I. Body: A.=B. Scene III.: on each side two dogs and a doe; on B. the warrior has no shield. Under handles a sphinx and a small boy. Micali, Storia 756 . 
24. Bonn, Kunstmuseum. Neck: A.=B. Scene VII.: on B., long-robed man in Hermes' place. Body : A. Scene V, B. Scene I. Under handles swan and pegasos.

25 (R). Corneto, Museo Bruschi. Neck: A.=B.: winged man between two men. Body : A. =B. Scene I.

26 (A). Museo Gregoriano, ii. 30. Vulci. Neck: A.=B. Scene I. (one youth with aryballos). Body: A.=B. Scene I. Under one handle small rider. Reisch-Helbig, nr. 10 (ii. 237).

27. Arezzo, Museo civico. Neck missing. Body: A. woman with wreath between men. Fragmentary.

(c) Palmette and lotos chain on neck :-

28. Brit. Mus. B 153. A. Scene VI.: man with doe opposite Dionysos; no Sileni. B. Scene V.: modified as a picture of Achilles pursuing Troilos (see aboze, p. 155). Flying birds on either side. Under handles: $(a)$ naked man with hare and long-robed man with fillet, (b) man with chlamys and doe.

29. Orvieto, Mus. Munic. 239. A.=B. Scene VI.: Silenus and Maenad, bird with snake in beak, naked man opposite Dionysos. Under handles: $(a)$ man with chlamys, $(b)$ Silenus and Maenad.

$30(0)$. Orvieto, Mus. Munic. 460. A.=B. Scene IV.: round shields with flying eagles. Under each handle a Silenus (head in front view) and Maenad.

31 (P). Orvieto, Museo Faina 63. A.=B. Scene IV.: shields as 30. Under handles Silenus and Maenad as 30 .

32 (C). Munich, 77. Vulci. A. under one handle a burning altar : towards it six longrobed men to $\mathrm{r}$. holding: 1. myrtle branch and wreath; 2. myrtle branch and oinochoe; 3. oinochoe and plate with cakes on his head, a ram beside him; 4. blowing double flute; 5. as 1 ; 6. uplifted hands ; flying bird. B. Scene VI.: ram before Dionysos; no Sileni. Under handles long-robed men. Micali, Mon. in. 44, 1.

33 (D). Munich, 79. A.=B. Scene IV.: a long-robed man between the warriors. Under one handle a tripod. Micali, Mon. in. 44, 2.

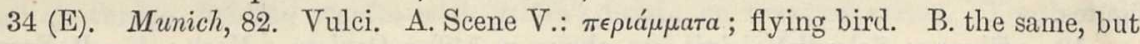
in front of rider a man in short chiton, nebris, chlamys, pilos. Under one handle man in chlamys pursuing a woman.

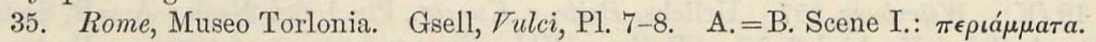

36 (F). Berlin, 1715. A. Scene IV.: two spectators holding lotos blossoms ; flying birds. B. procession of men, among them Hermes (see above, p. 156). Under each handle three small figures; one holds a cock ; on other side a dog.

37 (I). Würzburg, 313. Vulci. A. Scene VI.: Dionysos with winged shoes, opposite him man with chlamys and doe beside him : behind him a woman. Two birds with griffin's heads perched on the handle volutes. B. Scene IV.: two birds perched on handle volutes. Under handles gesticulating men. Micali, Storia, 77-8.

38. Würzburg, 338. A.=B. Scene VI.: Silenus between Dionysos and the man opposite him. Under handles running Sileni, one holding a cup.

39 (B). Museo Gregorians, ii. 31 (Reisch-Helbig, nr. 9, ii. 237). A. Scene VII.: folding chair, behind 'Zeus' a winged man, and a cock; Hermes with кißı⿻ı. B. the same, but winged man in front of 'Zeus': behind him man with chiton and nebris. Under each handle two female panthers killing a doe. The whole body striped: cf. the Attic amphora Vienna 229 Masner.

$$
\mathrm{II}^{\mathrm{a}} \text {. or } \mathrm{II}^{\mathrm{b}} \text {. }
$$

40. Perugia, Museo civico. Only neck preserved. A. Scene I.

$$
\mathrm{II}^{\mathrm{b}} \text {. or } \mathrm{II}^{\mathrm{e}} \text {. }
$$

41. Louvre F 21. Neck modern. A. long-robed man standing before tree to r., another bringing him a small boy (see above, p. 153): three others as spectators. B. Scene II. Under each handle smąll bearded rider, above him a flying bird, 
NOTES ON AMASIS AND IONIC BLACK-FIGURED POTTERY. 163

42 (G). Gerhard, $A V \cdot 117 / 8$. A. Herakles pursuing Nessos ; woman among spectators; flying bird. B. Scene IV.: woman among spectators; flying bird. Under handles small men, one winged.

$43(\mathrm{~J})$. Adria, Museo Bocchi 7. A. Scene V., B. Scene I.: one man holds cup, the one opposite a wreath, and a doe by the neck. Schöne, Mus. Bocchi, p. 26, Pl. XV.1-2=Micali, Mon. in. 47.

44. Naples, Coll. Santangelo. A variation of IIc, showing all the ornamental patterns on neck and body, even the tongue-pattern round the handles, but no figures, the rest of the body being painted black.

\section{APPENDIX II.}

\section{Note on the Origin of the Double Rays as an Ornament.}

With the exception of a few remarks by Pottier (B.C.H.xix. 227), this peculiar decorative pattern has never been examined. It was evidently designed originally to imitate the chalice of a lotos flower, which was supposed to support a vase with a rounded bottom : as such we find it on Egyptian vases (e.g. Pottier, Vases du Louvre, Pl. 9, A 234), and later on the alabastra of so-called 'Egyptian fayence,' which seem to have been made in Greek colonies on the Egyptian and Syrian coast (e.g. Perrot-Chipiez, iii. Pl. 5). The Greek potters, by adding a foot to their vases, obviated the necessity of separate supports, and thus, from an imitation of such supports, the rays became a purely decorative pattern, encircling the base of the vase; just as we have seen that the 'polypus' pattern develops probably into a band of crescents (see above, p. 145, n. 3). One would suppose that the oldest Greek vases showing rays would prefer the double row most resembling the original lotos chalice; but, on the contrary, both the geometric proto-corinthian and the 'italo-geometric'1 series, while constantly using rays, show an exclusive preference for a single row of them. Among the finest proto-corinthian vases, decorated with human figures and animals, we first find, not only double rays, but a variation peculiar to this class, the ends of the rays being alternately recurved. ${ }^{2}$ The connection between these vases and Ionic art is growing more and more apparent, and it is thus but natural that double rays are frequent on Ionic vases. I have noted them in the Cyrenaic class (Louvre, E 691, 692 and Brit. Mus. B 58. where pomegranates on long stalks alternate with the rays : A.Z. 1881, Pl. 10, 11), and on vases the exact origin of which has not been determined: a beautiful crater in Comm. Castellani's collection at Rome, one of the deinoi discrissed above (p. 144 : Vienna 215 Masn.), and the small series represented chiefly by the Northampton amphora (p. 146).

Double rays are further frequent in Corinthian pottery, both archaic and later, ${ }^{3}$ while in Attica they are an entirely foreign importation, and very rare. They are peculiar to that small group of very archaic amphorae, of which the 'Netos' vase is the finest example (Ant. Denkm. i. 57, Benndorf, Griech. Sic. Vas. 54, 1-2, Ephi. archaeol. 1897, Pl. 5-6), and I have also found them on three Corintho-Attic amphorae (Louvre E. 721, 773, 275). Among Attic b.f. vases the only example known to me (beside Amasis) is a crater by

1 Cf. Karo, Bull. d. Paletn. Ital. 1898, 148 : on the Greek geometric series and the Cypriote vases, rays do not yet appear. The Milesian potters use a lotos chain instead.

2 Double rays: two lekythoi (A.Z. 1883, Pl. 10, 1, 2) and two skyphoi (Brit. Mus. A 1530, Vienna 98 Masn.). Alternately recurved: four lekythoi (Berlin, Arch. Anz. 1888, 247, 1895, 33. Corneto, Mus. munic., Arch. Anz. 188, 247. Syracuse, Not. d. Sc. 1895, 190).

3 Early Corinthian : skyphoi: Louvre L 166.
Berlin 970. Vienna, Hofmus. 182 (Arch. Anz. 1892, 171); pyxides: Louvre L 159. Berlin 990 ; oinochoe: Louvre L 158; kylix: Coll. Somzée 104, Furtw. ; amphoriskoi: Brit. Mus. B 41, Ath. Mitth. xix. Pl. 8; statuette vase published by Pottier, B.C.H. xix. 227, Pl. 19-20. Later Corinthian: hydria: Louvre E $6 \pm 1$; amphorae: Louvre E 755 bis, 757 . Rouen, Mus. archéol. Brit. Mus. B 19. Vienna 137 Masn. Naples 336. 


\section{NOTES ON AMASIS AND IONIC BLACK-FIGURED POTTERY.}

Nikosthenes (Wien. Vorl. 1890-1, 5), who was strongly influenced by Ionic models (Loeschcke, A.Z. 1881, 31, Pottier, B.C.H. xvii. 431). It is thus of great importance that both Amasis and the affected amphorae employ only the double row of rays: while they appear but as an isolated phenomenon in other series, ${ }^{1}$ here it is an absolutely.constant peculiarity, just as it is in the Ionic 'Northampton' group, which we have seen to be akin to them.

\section{NOTE}

Further evidence as to the oriental influences traced by Mr. Karo in the 'affected' vases is hardly required; but it may be of interest to note an analogy between the type represented on the vase in the Bruschi Museum ( $\mathrm{Mr}$. Karo's 4B) and certain types on the silver coinage of Nagidus in Cilicia, where, it need hardly be said, oriental influence was strong. These coins are of course much later than the vases, but types of this kind always preserve ancient features.

1. NATI $\triangle I K O N$ Aphrodite, draped and wearing polos, seated r. on throne flanked by sphinxes, smelling flower which she holds in her 1.; in $\mathrm{r}$. phiale. [Obv. Head of Ares and name of Pharnabazus in Aramaic letters]. Persic stater. Babelon, Perses Achéménides, p. xxxvii.

2. Aphrodite, draped and wearing polos, seated 1 . on throne flanked by two sphinxes, smelling flower which she holds in her r.; her l. elbow rests on arm of throne. [Rev. Copy of Athena Parthenos]. Persic stater. ImhoofBlumer, Monnaies grecques, Pl. G. 15.

3. Aphrodite, draped and wearing polos, seated 1. between two sphinxes, smelling flower which she holds in $\mathrm{r}$. ; in 1 . flower on long stalk held over her shoulder like a sceptre. [Obv. Beardless head 1.]. Persic obol. ImhoofBlumer, op. cit. p. 372 , No. 75 .

4. Aphrodite, draped and wearing polos, seated 1. on throne, in r. phiale, 1. rests on arm of throne; in field Eros flying towards her with wreath held in both hands; before her feet, flower and bud growing on long stalks; under throne, mouse 1. [Rev. Bearded Dionysus standing]. Babelon, Inventaire Waddington, No. 4404.

All these types, of which Nos. $1-3$ can be dated approximately to 379-374 B.c., while No. 4 belongs to the period $374-333$ B.c., obviously show strong oriental influence, which probably came chiefly by way of Cyprus. We may compare, for instance, the association of the sphinx and lotos-flower with Aphrodite on the coins of Idalium, and a fine terra-cotta in the British Museum, from Larnaka (No. C 80): Female figure, wearing decorated polos, seated on throne flanked by sphinxes; in r., which rests on her knee, a flower; l. enveloped in drapery and raised to 1 . breast.

G. F. HILL.

\footnotetext{
1 All the examples known to me make up a very considerably smaller number than our list of affected amphorae,
} 


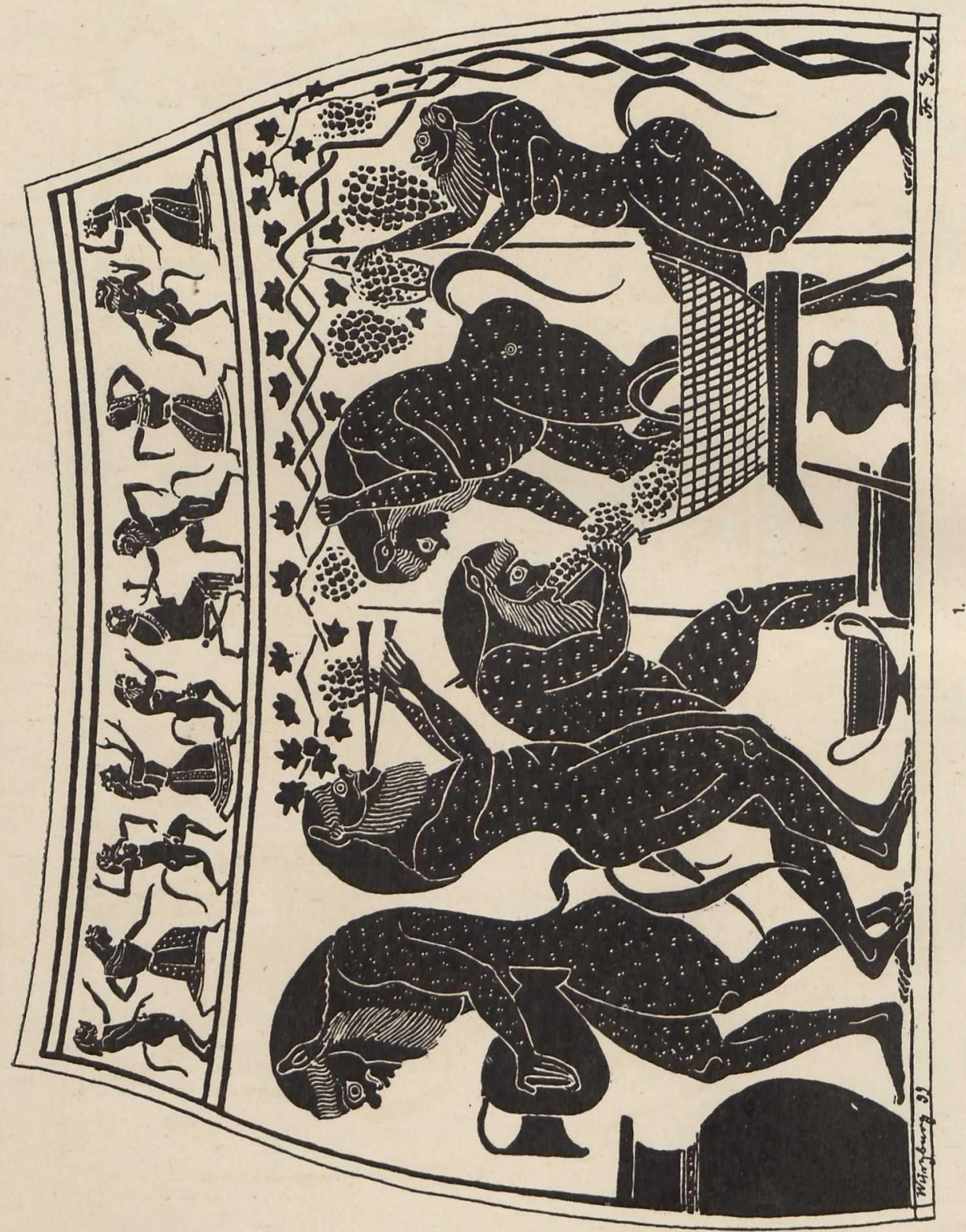


J.H.S. VOL. XIX. (1899), PL. V.

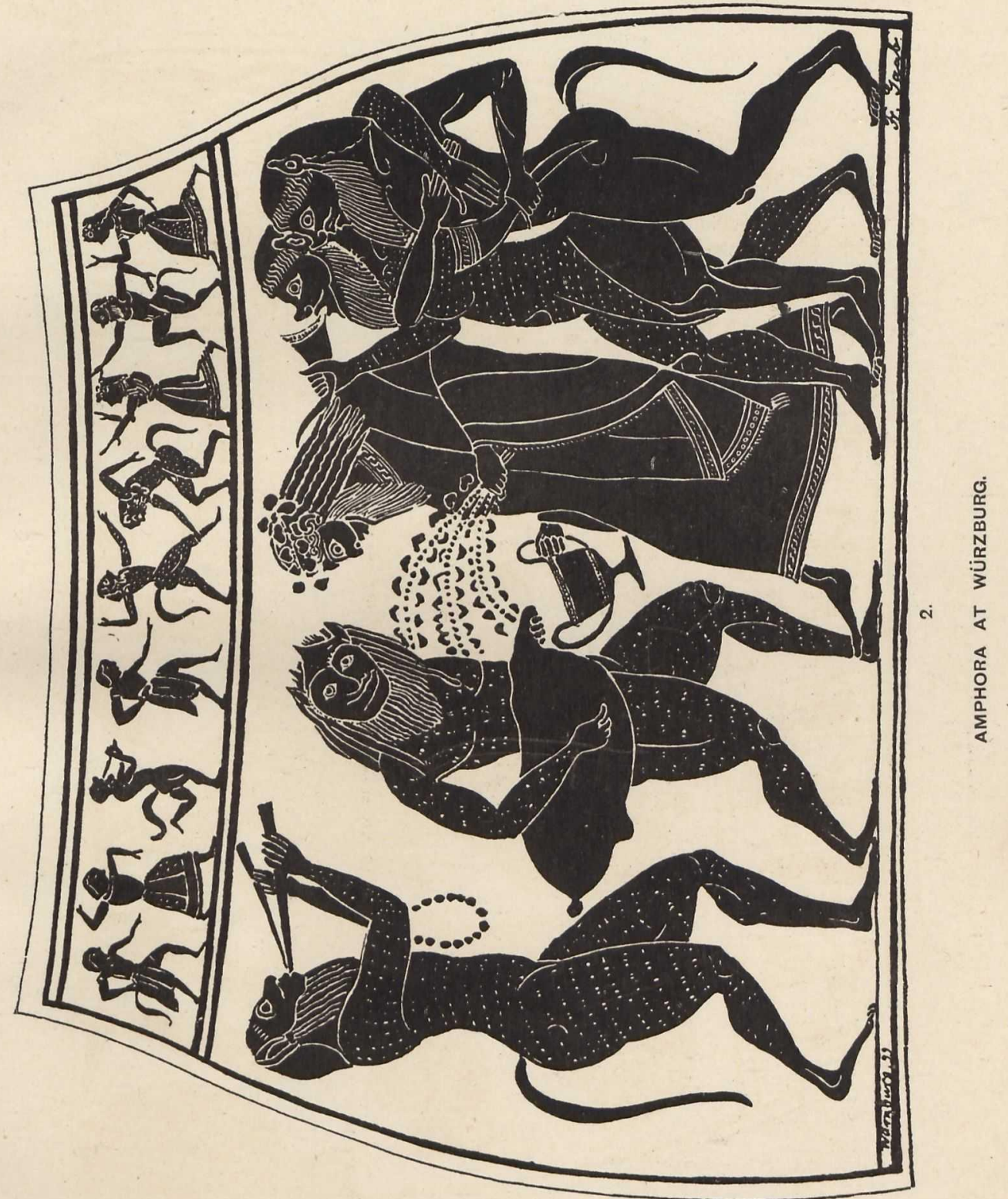




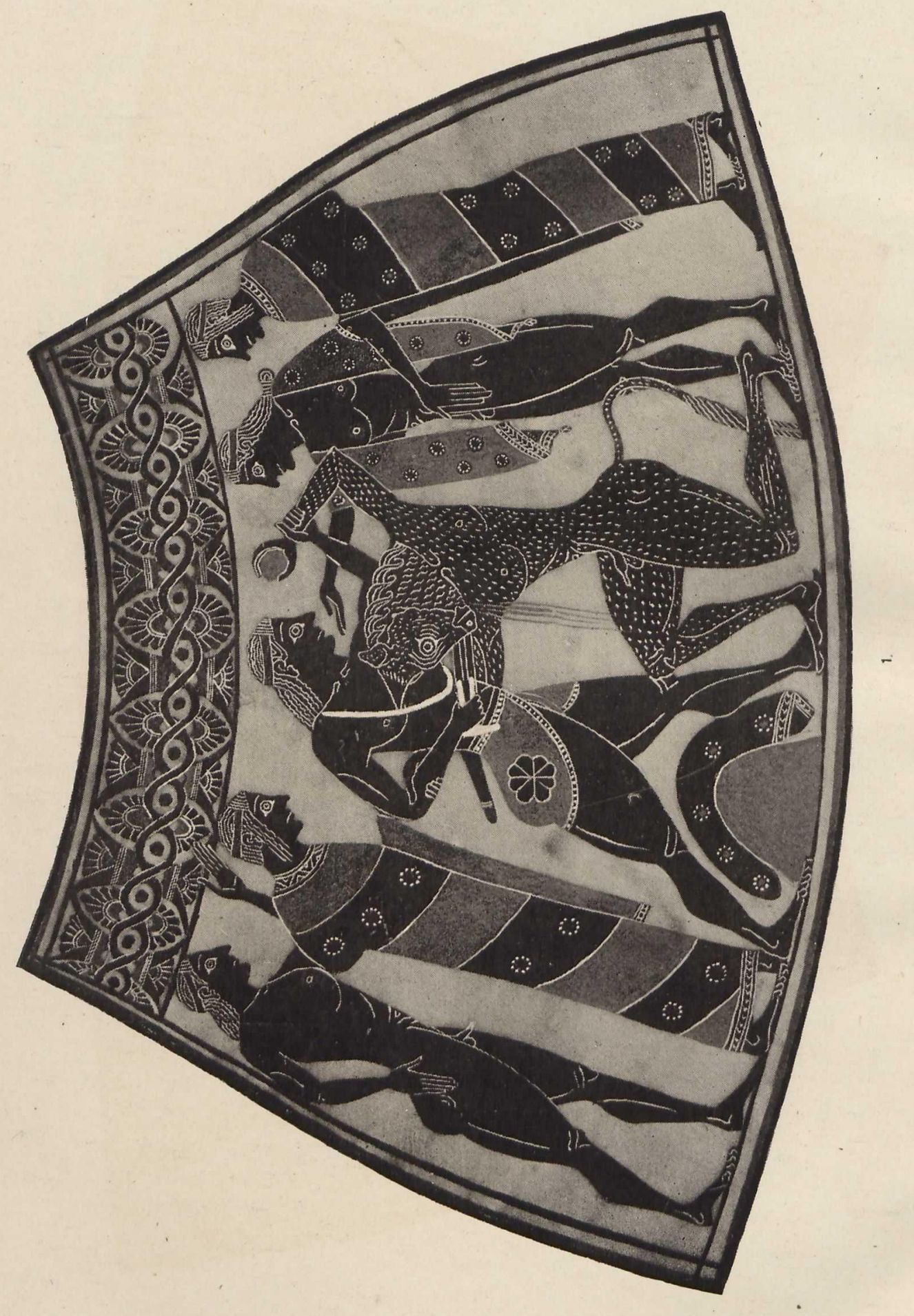


J.H.S. VOL. XIX. (1899). PL VI.

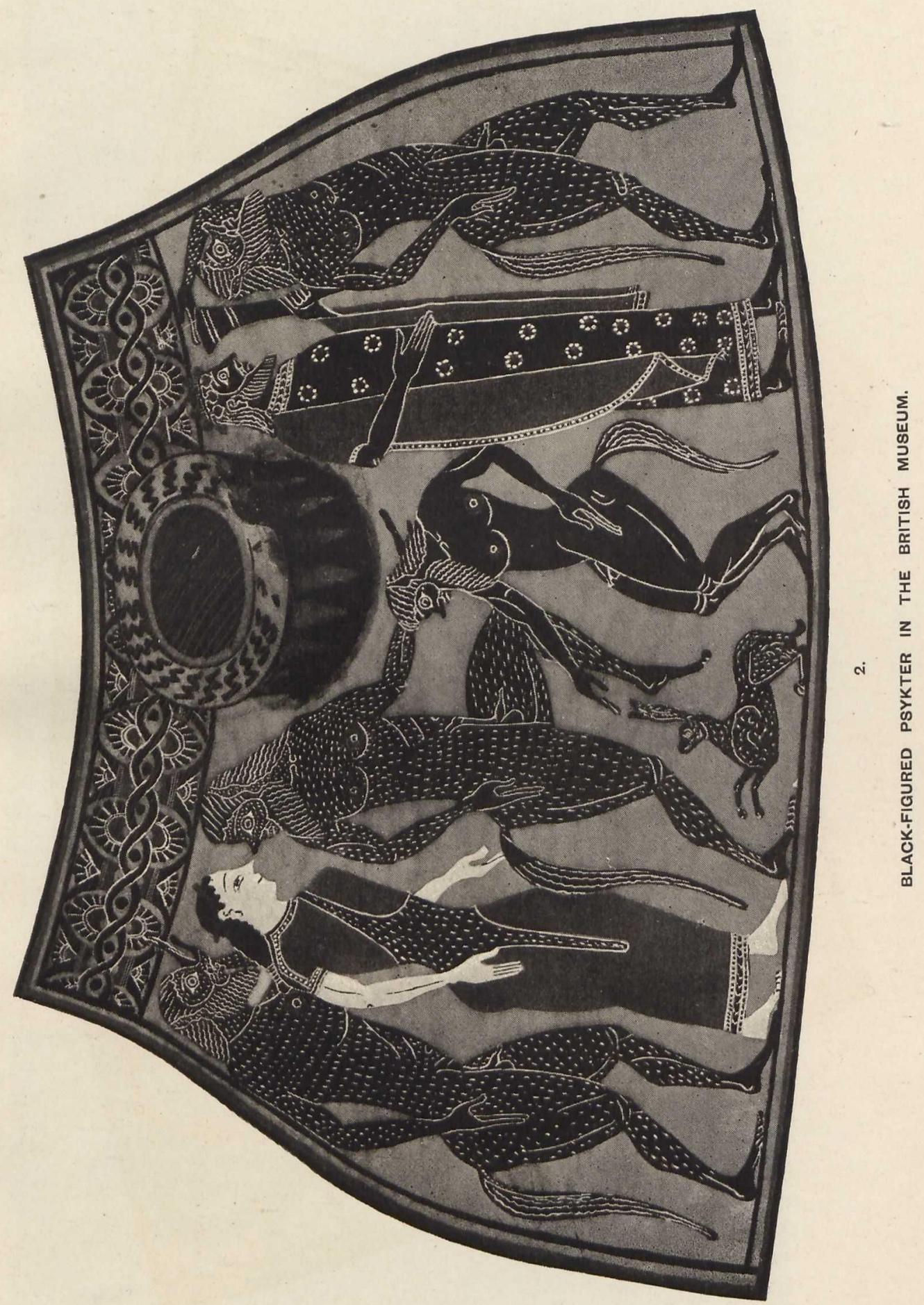

